University at Buffalo School of Law

Digital Commons @ University at Buffalo School of Law

\title{
Representing Nazism: Advocacy and Identity at the Trial of Klaus Barbie
}

Guyora Binder

University at Buffalo School of Law

Follow this and additional works at: https://digitalcommons.law.buffalo.edu/journal_articles

Part of the Criminal Law Commons, and the International Law Commons

\section{Recommended Citation}

Guyora Binder, Representing Nazism: Advocacy and Identity at the Trial of Klaus Barbie, 98 Yale L.J. 1321 (1989).

Available at: https://digitalcommons.law.buffalo.edu/journal_articles/294

\section{C) ${ }_{\text {COPYRIGHT }}^{\text {N }}$}

This Article is brought to you for free and open access by the Faculty Scholarship at Digital Commons @ University at Buffalo School of Law. It has been accepted for inclusion in Journal Articles by an authorized administrator of Digital Commons @ University at Buffalo School of Law. For more information, please contact lawscholar@buffalo.edu. 


\title{
Comments
}

\section{Representing Nazism: Advocacy and Identity at the Trial of Klaus Barbie}

\author{
Guyora Binder†
}

Among the ashes of the dead at Auschwitz, graverobbers found a jar. In this jar was a diary, with directions for finding other diaries. The diaries were written by the Sonderkommando, inmates charged with disposing of the dead, which they did. But as they worked, they recorded their deeds, so that the dead they incinerated would leave behind a residue of writing: "At 10:00 in the morning, I have just burned my parents," reports one diary. ${ }^{1}$ At 10:10: "I have just burned my wife." And finally, at 10:20: "I have just burned my children." 2 Perhaps some inmates accepted this grisly assignment in hopes of saving themselves, but most must have known they would last two months more at most, under conditions in which only death offered mercy. We must assume that those who wrote to us thus perpetuated their pain for one reason only-to communicate it to us. Accordingly we, the living, are derelict if we do not remember this pain. ${ }^{3}$ But should we also learn from it? Can we really hope to rectify it by discovering its lessons? May we recover knowledge from the ashes of Au-

$\dagger$ Professor of Law, State University of New York at Buffalo. I am indebted to Jonathan Bush, George Fletcher, Rodolphe Gasché, Richard Hyland, George Kannar, Muhammad Kenyatta, Virginia Leary, Patrick Martin, Errol Meidinger, Judith Olin, Robert Steinfeld and Victor Thuronyi for helpful suggestions. Errors are mine alone. Nina Cascio's indispensable reference guidance and her Mead Data Central grant for exploring the international human rights research applications of NEXIS facilitated this project. Candace Bell and Dr. Denise Bacardi provided invaluable assistance by translating many French materials. This essay is dedicated to Judith Olin, in recollection of the first of many common struggles.

1. 1 E. Wiesel, Against Silence: The Voice and Vision of Eli Wiesel 119, 136-37, 211-12 (I. Abrahamson ed. 1985).

2. Id.

3. Id. 
schwitz, and walk away enriched? This Commentary on the trial of Klaus Barbie argues that we must not allow ourselves to be edified by atrocity.

And yet this trial, "the most controversial in France since [that of] Dreyfus," and "one of the three great war crimes trials in the West," was greeted as an occasion for self-improvement. The French government promised "a pedagogic trial." that has educational significance." The New York Times hoped the trial would "educate a new generation,"8 while a representative of French Resistance veterans hoped it would "deepen our understanding." Nazi hunter Simon Wiesenthal felt that the trial would be "a proper history lesson," and that its true significance was "symbolic."10

Accordingly, the trial's chroniclers treated it as an object for interpretation: social historian Emmanuel Roy Ladurie predicted that it would be "an enormous national psychodrama."11 Few of the 800 journalists or forty attorneys present at the trial failed to speculate on its "meaning"-its meaning for France, its meaning for the West, even its meaning for the "New Novel."12 The Los Angeles Times observed that the trial sessions "seemed more like performances than presentation of information," and that "newspaper accounts read like reviews of a play."13

Some saw the trial as an even bigger show business phenomenon. The Barbie trial promised to become a major motion picture, and a struggle ensued for its direction. Defense attorney Jacques Vergès, noting that crime is the source of the greatest literature, announced that he was a film director, shaping a story out of the rushes provided by the dossier and testimony. ${ }^{14}$ Marcel Ophuls, film chronicler of French collaboration and Allied justice, impatiently awaited the trial so that it could provide the conclusion of his film on the life of Klaus Barbie. ${ }^{15}$ While the entire trial was being filmed by the government, ${ }^{16}$ French TV viewers were shown Claude Lanzmann's Shoah for the first time. The depressing documen-

4. Rosemberg, Barbie's Lawyer, From Guerilla Gun-Running to Nazi's Defence, Reuters, May 11, 1987 (NEXIS) (paraphrasing defense attorney Jacques Vergès).

5. N.Y. Times, Aug. $2,1987, \S 6$, at 20 , col. 1 (late city final ed.) (with the Nuremberg and Eichmann trials).

6. French Hope Barbie Trial Will Not Become Trial of Their History, UPI, May 12, 1987 (NEXIS).

7. Immanuel, Israelis Offer to Help Prosecute Barbie, AP, Feb. 6, 1983 (NEXIS).

8. The Barbie Trial: Not Just Vengeance, N.Y. Times, May 14, 1987, § A, at 30, col. 1 (late city final ed.).

9. N.Y. Times, May $11,1987, \S \mathrm{A}$, at 1, col. 1 (late city final ed.).

10. Barbie-Wiesenthal, Reuters, Feb. 7, 1983 (NEXIS).

11. The Trial of Vichy France, THE Economist, Feb. 12, 1983, at 55.

12. Solomon, Klaus Barbie and The Conscience of the Literati, N.Y. Times, Aug. 3, 1986, § 7, at

1, col. 1 (late city final ed.).

13. L.A. Times, July 5, 1987, $§ 5$, at 2 , col. 1 (home ed.).

14. Rosemberg, supra note 4.

15. Film: Marcel Ophuls on Barbie, N.Y. Times, Oct. 2, 1988, § 2, at 21, col. 1 (late city final ed.).

16. Film: Bearing Witness, N. Y. Times, Aug. 30, 1987, $\S 6$, at II-38, col. 1 (late city final ed.). 
tary's audience of 4 million, in the eyes of some observers, proved the trial's success. $^{17}$

Why? Why was this trial, France's most important trial, ten-thousand times a murder trial, important, above all, as culture?

In answering this question, Section I recapitulates the forty year evolution of Barbie's case to recall how he came to public notice first as the slayer of a hero of the French left, then as the slaughterer of Jewish children, and finally as the brutal henchman of a deposed Bolivian dictator. Barbie, adept at making himself useful to governments, would never have been captured had he not come to symbolize causes that transcended his crimes. Captured and charged with "crimes against humanity," Barbie served as an emblem of Nazism. Anxious to distinguish the atrocities suffered by French partisans from those later suffered by Algerian rebels, the French courts made Nazi ideology an element of "crimes against humanity." In sum, Section I explains how the Barbie trial's historical background and legal framework invited the prosecution and defense to conduct an edifying debate on the meaning of Nazi crimes.

Section II reveals that groups associated with the prosecution-the French government, Resistance veterans, Jewish survivors, and the Israeli government-greeted this invitation as an opportunity to define themselves by contrast to Nazism. Focusing on the influential efforts of prosecution witness Elie Wiesel to root Jewish identity in the memory of the Holocaust, Section II argues that identities defined by reference to an enemy are inauthentic and ethically impoverished.

Section III applies this same criticism to the controversial defense offered by Barbie's radical attorney Jacques Vergès. While the prosecution case defined Judaism and French nationalism by contrast to Nazism, the defense defined national liberation movements by contrast to Nazism. Cynically assuming that society inevitably embodies deceit and contradiction, Vergès aspired to expose Western hypocrisy by conducting what he called a "defense of rupture." He agreed to represent a Nazi in order to unmask colonialism as the equivalent of Nazism. The difficulty is that anticolonial movements traditionally aspire to embody not only the suffering, but also the authentic values of their peoples. Vergès' cynical assumption that society is inherently inauthentic prevents him from identifying with the anticolonial causes he advocates.

The disabling assumption that authenticity is impossible prevails increasingly within the French left as a result of the popularity of poststructuralism. No one better illustrates the convergence of the postwar identity crises of Judaism and French radicalism than post-structuralist theorist Jacques Derrida. Section IV reads Derrida's "deconstruction" of the concept of identity as a despairing response to the Jewish ordeal in the

17. L.A. Times, supra note 13. 
Holocaust. Rejecting the concept of identity as part of the "logic" of Nazism, Derrida is forced into exile from his own Jewish identity, driven to the unacceptable conclusion that one cannot claim a Jewish identity as authentically one's own without becoming a Nazi.

That we should not define ourselves by contrast to Nazism does not mean that we cannot identify ourselves at all. The perspective taken in this Commentary is that people must identify their value commitments in order to act morally, and that self-definitions rooted in persecution enable them to escape that obligation. Accordingly, those who define themselves by condemning the oppression of others, benefit unjustly from the persecution they so piously abhor. This Commentary's conclusion is that no one can learn lessons from atrocity without also rationalizing it; no one can rectify atrocity without also justifying it; and no one can be improved by atrocity without being implicated in it. Self-definitions prove valueless when they are accepted from killers in payment for the dead.

\section{How Nazism Was Brought to Trial}

The interpretation of Klaus Barbie began long before his trial; otherwise he would never have come to trial at all. Barbie became a target for French justice because he was successively associated with collaboration and betrayal among the Resistance, with the murder of Jewish children; with the martyrdom of the French Left, and with Latin American dictatorship. After Barbie's capture, French courts surmounted legal obstacles to try him in hopes of contrasting French values with his Nazi ideology.

\section{A. A Representative Nazi}

The history of the past is never of the past only. It consists in small part of the record of acts, in large part in the ever lengthening shadow of their memory. Klaus Barbie's role in the enormous criminal activity of the Nazi state-his crime-was that of a minor lieutenant. But the memory of Klaus Barbie's crime-his case-grew in significance until, by the time of his trial, it seemed to stand for the whole of Nazism, and for much more besides.

\section{The Case of Barbie}

Born near Germany's French border, and of partly French extraction, Barbie lost his father to the lingering effects of a World War I wound in 1933. The following year, Barbie graduated from high school. Finding himself penniless and without prospect of employment, Barbie became involved with the Nazi movement and in 1935, was accepted into the SS. ${ }^{18}$ "Any idiot couldn't join the SS," Barbie has insisted. "I had to study law

18. T. Bower, Kiaus Barbie, The Butcher of Lyons 20-21 (1984). 
and philosophy."19 Barbie became a lieutenant in the intelligence section of the SD in 1940. He was posted to occupied Holland where he participated in roundups of Jews for deportation and execution. ${ }^{20}$

Because of his fluency in French, Barbie was moved to occupied France in 1942; towards the end of the year he became head of the Gestapo in Lyons, ${ }^{21}$ the center of Resistance activity in the South. ${ }^{22}$ His chief responsibilities were the suppression of the Resistance, communists and Jews. ${ }^{23}$ Historians estimate that more than 4,000 people were executed on his orders during the last two years of the Occupation. ${ }^{24}$ In addition, the records of a local magistrate indicate that the Gestapo deported 7,591 people from Lyons to the death camps; but "shot or deported, there's no difference," Barbie reportedly philosophized. It is not known how many of these approximately 12,000 victims were Jewish. ${ }^{25}$ Barbie's reputation as the "Butcher of Lyons" rested also on his routine practice of torturing suspected Resistance members and Jews in an effort to uncover other members of both groups. ${ }^{26}$

Immense as these crimes are, they constituted but a trickle amid the Nazi torrent of death. In all, this minor lieutenant carried out or facilitated perhaps one tenth of one per cent of all the executions mandated by his superiors. ${ }^{27}$ What would eventually make his name a household word in France, however, was the capture and death under torture of just one victim-Jean Moulin, the leftist leader of the unified Resistance in France. ${ }^{28}$ Handsome, charismatic and capable, Moulin was mourned by the French left as a leader whose postwar popularity might have rivaled De Gaulle's.

At war's end, the French government named Barbie as a wanted man, but did not pursue him. From 1945 to 1947, Barbie lived a shadowy existence as a fugitive in occupied Germany; but by 1947, the United States occupation force had lost interest in the punishment of war criminals. The American Counter Intelligence Corps (GIC) hired Barbie to gather information about communists in France, Germany and Eastern Europe. ${ }^{29}$

\footnotetext{
19. Id. at 208.

20. Id. at 26-27.

21. Section IV of the SD (Sicherheitsdienst, an elite subdivision of the SS).

22. T. BOWER, supra note 18 , at 28 .

23. Id. at 40 .

24. Pre-trial probe of Nazi War Criminal Completed, U.P.I., July 20, 1985 (NEXIS). Bower offers the very precise figure of 4,342 without explanation. T. BowER, supra note 18 , at 16 .

25. T. BOWER, supra note 18 , at 58-60.

26. Id. at 51-64.

27. It was not unusual to find minor officers exercising great power over life and death in the Nazi regime. See Jackson, Report to President Truman on the Legal Basis for Trial of War Criminals, 19 TEMP. L.Q. 144, 148, 149 (1946).

28. A. CASSESE, VIOLENCE AND LAW IN THE MODERN AGE 116 (1988) (Barbie's notoriety based on Moulin's importance and popularity).

29. T. BowER, supra note 18, at 137-54.
} 
One of Barbie's American employers praised him as "strongly anticommunist and a Nazi idealist."

In the postwar period France was more interested in the crimes of French collaborators than those of German occupiers. Barbie first attracted the attention of the French public in 1947, weeks after Resistance leader René Hardy was acquitted of informing against Moulin. Hardy was rearrested following the discovery that Barbie had interrogated him shortly before capturing Moulin. Public pressure mounted to locate Barbie as a prosecution witness. ${ }^{31}$

In 1948, the CIC permitted French officials to interrogate Barbie, who did name Hardy as his informant. Nevertheless, the GIC would not turn a valued agent over to the French, whom they considered communists. ${ }^{32}$ For two years, unsuccessful attempts to summon Barbie brought his own crimes under increasing scrutiny in France. At the end of this period, the Americans offered Barbie's services as a witness against Hardy, on the condition that he be returned. Now interested in trying Barbie as well, the French government could no longer accept this condition. Lacking Barbie's testimony, Hardy's prosecution failed again, this time provoking a public furor in France against both the American government and Barbie. ${ }^{33}$ In the face of increasing French pressure, the American government in 1951 smuggled Barbie out of Germany to Bolivia, where he was welcomed by a German emigre community which owned 60 percent of the Bolivian economy. ${ }^{34}$

In 1952, a French military tribunal sentenced Barbie to death in absentia for executions and deportations of suspected Resisters in the Jura region during April of 1944. In 1954, Barbie was again sentenced to death for a number of executions committed in the Montluc prison. ${ }^{35}$

Meanwhile, Barbie prospered in Bolivia. Entering the timber trade, Barbie became a Bolivian citizen in 1957 under the name of Klaus Altmann. In 1961 he was identified by German prosecutors, who informed the French security services in 1963. However, neither country had an extradition treaty with Bolivia. In 1966, the increasingly influential

\footnotetext{
30. Id. at 140 .

31. Id. at 160 .

32. Id. at 160-68; Hotel Terminus, The Life and Times of Klaus Barbie (S. Goldwyn 1988) [hereinafter Hotel Terminus] (interview with Eugene Kolb).

33. T. BOWER, supra note 18 , at $160-68$.

34. Id. at 173-81; R. WiLson, The Confessions of KLAus Barbie 92 (1984). For the official United States government account of its relations with Barbie, read, with skepticism, A. RYAN, Klaus Barbie and the United States Government: A Report to the Attorney General oF THE UNITED STATES (1983).

35. T. BOWER, supra note 18, at 184. According to Bower's account, it does not appear that any of Barbie's Jura region victims were killed because they were Jewish. Nevertheless, some of the crimes charged at Barbie's early trials were committed against Jews. Judgment of Dec. 20, 1985, Cass. crim. Fr. (No. 859-5.166, LEXIS).
} 
Barbie organized a state-sponsored shipping business which enabled him to become an arms merchant. ${ }^{36}$

The following year, Ghe Guevara and French writer Régis Debray were captured, waging a guerilla war in the Bolivian countryside. While Guevara was shot, Debray was released in 1970, when a leftist regime took power. ${ }^{37}$ For Debray, Barbie would become a symbol of Bolivian injustice. In 1971, Nazi-hunters Serge and Beate Klarsfeld launched a publicity campaign that focused on Barbie's deportation of one group of Jewish children to the deathcamps. The publicity forced German prosecutors to reopen Barbie's dormant file, and induced the French government to request Barbie's extradition. ${ }^{38}$ But in the meantime, Colonel Hugo Banzer, a member of Bolivia's powerful German community, had seized the government with arms supplied by Barbie. ${ }^{39}$ In 1973, the extradition request was rejected, ${ }^{40}$ and the fall of the Allende regime foiled a plot by the Klarsfelds and Debray to abduct Barbie to Europe via Chile. ${ }^{41}$

Barbie remained influential in Bolivian politics throughout the seventies, despite another change of regime. Finally, in 1980, he organized a mercenary army of German and Italian neofascists that helped effect a coup that brought Bolivia's leading cocaine barons to power. ${ }^{42}$

In 1982, however, the left-leaning President Siles-Zuazo was elected in Bolivia, while a socialist government dominated by Resistance veterans had come to power in France. Régis Debray was now President Francois Mitterand's special assistant. At Debray's urging, the French government apparently offered Bolivia an aid package in return for Barbie, whom the Bolivians were now only too happy to deport. ${ }^{43}$ Germany also submitted an extradition request." In February of 1983, Barbie was expelled to France. ${ }^{45}$ After three years of investigation and litigation, Barbie was charged with six "crimes against humanity" involving the deportation of approximately 450 Jews and over 300 suspected Resisters to death camps, as well as the murder by torture of one Jewish Resister. ${ }^{48}$ On May 11, 1987, Barbie's trial commenced. Forty civil prosecutors, representing Barbie's victims and their relatives, joined the state prosecutor in summing

\footnotetext{
36. T. Bower, supra note 18 , at 191.

37. Id. at 16 .

38. Id. at 201-07.

39. Id. at 195,210 .

40. Id. at 209-10; Zeballos, Nazi Fugitive Klaus Altman, Reuters, Feb. 5, 1983 (NEXIS).

41. T. BOWER, supra note 18, at 15-16.

42. Id. at 214-15; Bolivia's Labor Union Movement, Reuters, July 30, 1982 (NEXIS).

43. T. BowER, supra note 18, at 16-17, 219; Intense Diplomatic Activity, Reuters, Feb. 12, 1983 (NEXIS); Convicled Nazi War Criminal, Reuters, Feb. 24, 1983 (NEXIS); Diehl, For Struggling Bolivia, Barbie Was a Convenient Gift to France, Washington Post, Feb. 25, 1983 (NEXIS).

44. T. BOWER, supra note 18 , at 219.

45. Id. at 224-25.

46. See infra notes 96,97 and 102 and accompanying text.
} 
up the evidence against Barbie. ${ }^{47}$ On July 4, he was convicted on all counts and sentenced to life imprisonment. ${ }^{48}$

\section{Barbie's "Ideals"}

From the time of his public exposure by Beate Klarsfeld in the early 1970 s, Barbie has offered a hungry world press numerous interviews. While admitting few specifics, he has supported those inclined to explain atrocity in terms of ideology. "I am a convinced nazi," "I stand to my opinion, right or wrong." "I would assess my life as being absolutely positive," he said, shortly after his arrest. ${ }^{51}$ While he doubts that six million Jews were killed, he praises Hitler for "doing away with 6.5 million unemployed" and is "sorry about every Jew that I did not kill." 12 Despite his ideological commitments, however, Barbie considers himself simply a professional soldier. His methods, he has said, are no more brutal than those used by the French in Vietnam and Algeria. ${ }^{\text {ss }}$ Nevertheless, Barbie feels that the brutal methods of all nations are ennobled by their ideals: "Israel is in the same situation that we have been during the war in the occupied countries. They have a resistance. And the Israeli people must defend. And that's the same thing that made the SS. Different people fight for country, for blood and to defend his ideals, his serious ideals. The commander from Israel imitated the SS commander. . . . He defends Zionist dignity."54 Barbie's unabashed adherence to Nazism reassured his prosecutors that he would be an edifying villain, articulating the "ideals" they sought to condemn as inhuman.

\section{B. "Crimes Against Humanity:" The Doctrinal Invitation to Represent Nazism}

In formulating the legal definition of Barbie's charges, the French judiciary designed his trial as a demonstration of the meaning of Nazism. The political and cultural importance of this lesson for France is revealed by the legal obstacles the French judiciary surmounted in order to stage it.

47. "Any person who claims to be injured by a felony . . . may, in bringing a complaint before the competent examining magistrate, constitute himself a civil party." C. PR. PEN. Fr. Art. 85 (1987). See also Id. Arts. 86, 87 (further requirements for joining criminal prosecution as civil party).

48. Korolyov, Barbie Sentenced to Life Imprisonment, TASS, July 4, 1987 (NEXIS). Lewis, Foreign Affairs; A Model of French Justice, N.Y. Times, July 6, 1987 (NEXIS).

49. T. BOWER, supra note 18 , at 208 .

50. R. WIISON, supra note 34 , at 126 .

51. Nazi Gestapo Chief Unrepentant, UPI Feb. 13, 1983, (NEXIS).

52. Barbie-Interview, Reuters, Feb. 9, 1983 (NEXIS).

53. T. BowER, supra note 18, at 209; 'Butcher of Lyon' Plans Defense Strategy, AP, Feb. 20, 1983, (NEXIS).

54. R. WIISON, supra note 34 , at 237 . 


\section{Obstacles to Prosecution in France}

France's prosecution of Barbie was problematic for several reasons. First, he could not be punished for those crimes of which he had previously been convicted. France's Code of Penal Procedure requires the execution of all criminal sentences within twenty years of conviction.5 Hence, France's highest court deemed Barbie's 1952 and 1954 sentences for "murders, arsons, pillages and arbitrary sequestrations" void as of 1972 and 1974, respectively. ${ }^{56}$

Having survived his death sentences, Barbie could not have been tried for offenses based on the same acts without violating France's constitutional prohibition on double jeopardy. ${ }^{57}$ Yet he could not be prosecuted for other acts of murder, arson and wrongful imprisonment, because France's general statute of limitations voids liability ten years after commission of such felonies. ${ }^{58}$

Hence Barbie remained liable only for imprescriptible crimes ${ }^{59}$ for which he had never been prosecuted previously. The only crimes deemed imprescriptible by French law are "crimes against humanity;" yet no such crime was defined by French law during the Occupation. In 1945, however, France joined the London Agreement conferring apparently retroactive jurisdiction upon the Nuremberg Tribunal to prosecute "crimes against humanity" committed by agents of the Axis powers. ${ }^{60}$ This treaty defined crimes against humanity as "murder, extermination, enslavement, deportation and other inhumane acts committed against any civilian population, before or during the war, or persecutions on political, racial or religious grounds in execution of or in connection with any crime within the jurisdiction of the Tribunal, whether or not in violation of the domestic law of the country where perpetrated."

55. C. PR. PEN. Fr. Art. 763 (1987).

56. "Crimes against humanity," recognized as a source of imprescriptible liability in 1964 , see infra notes 59-64 and accompanying text, constitute the only exception to this statute of limitations. While France's highest court later concluded that some of the acts for which Barbie was previously convicted met the definition of crimes against humanity, he was not so charged at the time. Judgment of Dec. 20, 1985, Cass. crim. Fr. (No. 85-95.166, LEXIS). According to a court of appeals order, quoted by this opinion, these crimes were characterized "by tortures and summary executions of members of the Resistance, of hostages and of Jews.' "Id. (D. Bacardi trans.) (on file with author).

57. See Judgment of June 3, 1988, Cass. crim. Fr. (No. 87-84.240 LEXIS) (denying motion to quash conviction on grounds that it was based on acts for which Barbie was previously convicted).

58. This ten year period is tolled from the last official act of investigation or prosecution if such official action commences within ten years of the commission of the crime. C. PR. PEN. Fr. Art. 7 (1987).

59. That is, crimes, the liability for which could not be extinguished by the passage of time.

60. London Agreement for the Prosecution and Punishment of the Major War Criminals of the European Axis, Aug. 8, 1945, United Kingdom-U.S.A.-France-U.S.S.R., 59 Stat. 1544, EAS No. 472, 83 U.N.T.S. 279 (1951). "Crimes Against Humanity," "War Crimes" and "Crimes Against Peace" are defined in the Constitution of the International Military Tribunal, Art. 6, id. at 288.

61. Id. The original english text placed a semicolon after the word "war." This was later changed to a comma by agreement of all the parties to the treaty. Wright, The Law of the Nuremberg Trial, 41 AM. J. INT'L L. 38, 61 (1947); J. Sweeney, C. Oliver \& N. Leech, The International Legal System 784 (1988). 
jurisdiction of the Tribunal" were "war crimes" and "crimes against peace" committed by agents of the Axis. ${ }^{62}$ All of the crimes against humanity charged to Barbie were probably also war crimes. ${ }^{63}$

In 1964, fearful that the punishability of ordinary felonies committed during the Occupation was expiring, the French legislature hurriedly passed a statute declaring that "crimes against humanity as defined in the United Nations Resolution of February 13, 1946, recognizing the definition of crimes against humanity in the August 8, 1945 Charter of the International Tribunal, are, by their nature, imprescriptible."64 As Barbie's attorney, Jacques Vergès, pointed out, this statute fails to specify that either liability for crimes against humanity, or its imprescriptability, shall be retroactive. ${ }^{68}$ Despite France's constitutional prohibition on retroactive punishment, ${ }^{68}$ however, France's highest court ruled that the 1964 statute validly acknowledged France's seemingly retroactive establishment by treaty of imprescriptible liability for "crimes against humanity."

Yet the London Agreement itself appeared retroactive in giving definition to crimes that took place before its ratification. ${ }^{88}$ It is therefore fair to ask how invocation of the London Agreement defeats the claim that Barbie's imprescriptible liability was created retroactively. The answer offered by the Office of Public Prosecutions and affirmed by France's high-

62. London Agreement, supra note 60, at 288. "Crimes against Peace" consist of planning or conducting agression. Id.

63. War crimes were defined as "violations of the laws or customs of war, including murder, illtreatment or deportation to slave labor or for any other purpose of civilian population of or in occupied territory, murder or ill-treatment of prisoners of war or persons on the seas, killing of hostages, plunder of public or private property, wanton destruction of cities, towns or villages, or devastation not justified by military necessity." Id. Barbie's actions might not have been considered war crimes on the assumption that Vichy France was not occupied territory, but an autonomous state no longer at war with Germany. On this view, captured Resisters might be considered criminals rather than prisoners of war. But see infra text accompanying notes 87-93, for discussion of civil war.

64. 1964 J.O. (Fr.) 11788, Law No. 64-1326 (26 Dec. 1964). See T. Bower, supra note 18, at 227-28 (describing circumstances of act's passage). The "U.N. Resolution" referred to "tak[es] note of the laws and usages of warfare established by the fourth Hague Convention of 1907" and "the definition of . . crimes ... against humanity contained in the Charter of the International Military Tribunal dated 6 August 1945." G.A. Res. 3(I), U.N. Doc. A164 at 10. After establishing the imprescriptibility of crimes against humanity in its own law, France was instrumental in the drafting of the Convention on Non-applicability of Statutory Limitations to War Crimes and Crimes against Humanity, U.N. G.A. Res. 2391/XXIII (Dec. 9, 1968). See Levasseur, Les Crimes Contre L'humanité at le Probleme Leur Presciption 93 J. Du Drort INT'L 259, 266 (1966).

65. See Judgment of Jan. 26, 1984, Cass. crim., Fr. (No. 83-94.425, LEXIS) (quoting appellant's brief).

66. Id.; This prohibition may be found in Const., Preamble (Fr.) (incorporating by reference The Declaration of the Rights of Man, art. 8).

67. The court approved the position of the Office of Public Prosecution that: "the law of December 26,1964 . . . contains a precise reference to the Charter of the International Tribunal, appended to the London Agreement of August 8, 1945,' the latter being integrated into the internal juridical order, and that the scope of this law 'necessarily proceeds from the international text with which it expressly forms a whole." "See Judgment of Jan. 26, 1984, supra note 65 (D. Bacardi trans.) (on file with author).

68. This objection was offered by Assistant Attorney General Herbert Wechsler as an American proposal for a war crimes trial was being developed. Wechsler would later serve as legal adviser to the Tribunal. B. Smith, Reaching Judgment at Nuremberg (1977). 
est court, was that "the incrimination of crimes against humanity is in accordance with the general principles of law recognized by the civilized nations . . . as such these crimes escape the principle of retroactivity." This is the same response offered by the Nuremberg Tribunal, and by leading scholarly interpreters of the London Agreement, to the charge that the Nuremberg prosecutions were retroactive. Their argument was that the London Agreement did not create liability for crimes against humanity, but merely recognized that such liability was already a part of customary international law. ${ }^{70}$ Accordingly, United Nations Resolution 95(I) affirmed "the principles of international law recognized by the Charter of the Nürnberg Tribunal and the judgment of the Tribunal." "71 In acceding to the London agreement, therefore, France affirmed the preexisting and universal authority of these principles of international law. ${ }^{72}$

What are the "principles of international law" that establish the criminality of crimes against humanity? This question has generated two responses. The view adopted by the Nuremberg Tribunal sees crimes against humanity as prohibited by the customary law of war. ${ }^{73}$ Adhering to this view, the International Law Commission redefined crimes against humanity as "inhuman acts committed against civilians or persecutions . . . when such acts are done or such persecutions are carried on in exe-

69. Judgment of Dec. 20, 1985, supra note 56.

70. "The Charter . . . is the expression of international law existing at the time of its creation." Proceedings of the International Military Tribunal SitTing at Nuremberg 433-44, (1950) quoted in Tornaritis, Individual and Collective Responsibility in International Criminal Law, 1 A Treatise on International Criminal Law 103, 113 (M. Bassiouni \& V. Nanda eds. 1973); 2 D. O'Connell, International Law 744 (1970) (Nuremberg Tribunal's judgment reflects scholarly tradition and progressive acceptance by states that "activities mala in se are juridically condemnable and that international law comprehends such activities."); Bierzanek, The Prosecution of IVar Crimes, 1 a TREatise on InTernational CRIminal. Law 559, 576 (M. Bassiouni \& V. Nanda eds. 1973) (London Agreement "founded on the premise that violation of the principles of international law entails, even when there are no specific provisions defining the implications of such a breach, liability in international law.").

71. G.A. Res. 95 (I), U.N. Doc. A/64/Add. 1 at 188 (Dec. 11, 1946). For a discussion of the legislative history of this resolution, see The Charter and Judgment of the Nuremberg Tribunal: History and Analysis, U.N. Doc. A/CN 4/5, at 11-33. United Nations Resolution 3(I), referred to in the French statute of 1964, refers more specifically to "the fourth Hague Convention of 1907." See supra note 64. This Convention has been consulted in interpreting "the principles of international law" referred to in Resolution 95(I). See infra note 78.

72. For the argument that the conception of crimes against humanity established in customary international law involved no notion of prescription, see Levasseur, supra note 64, at 275-76, 283.

73. 1 A Treatise on International CRIMINal LAw, supra note 70, at 613-14 (quoting From Judgment of The Nuremberg Tribunal, Sept. 30, 1946) (war crimes were recognized in the Hague Convention of 1907 , codifying preexisting custom. Crimes against humanity, as a form of war crimes, must take place during war, or in furtherance of other war crimes). The Tribunal's legal adviser, Herbert Wechsler, had always been uncomfortable about the international punishment of internal atrocities implicit in the concept of crimes against humanity. See supra note 68 . This may have caused the Tribunal to work at cross-purposes to its own charter. See Finch, The Nuremberg Trial and International Law, 41 AM. J. INT'L L. 20, 23 (1947) (Tribunal "disregards the express terms of the Charter on this particular definition."). The Tribunal's limitation of crimes against humanity to traditional war crimes was followed by some lower Allied tribunals as well. See Cowles Trials of War Criminals (Non-Nuremberg), 42 AM. J. INT'L L. 299, 309-13 (1948) (reporting U.S. military trial of sanatorium administrators for killing Polish and Russian citizens; murders of German citizens excluded from charges). 
cution of or in connection with any crime against peace or any war crime." $"$

The difficulty with this effort to absorb crimes against humanity into the uncontroversial category of war crimes is that it fails to explain why the allies found it necessary to invent a new category of international crime. By all accounts they did so in the belief that inhumane acts committed by the Nazi regime against its own citizens and those of its allies would not be punished under the customary laws of war. ${ }^{75}$ This belief is reflected in the London Agreement's specifications that inhumane acts could be punished as crimes against humanity if committed against "any" civilian population, even "before" the war." Supporting this interpretation, the original English text separated the clause on "inhumane acts" from the clause on "persecutions ... in execution of ... any crime within the jurisdiction of the Tribunal," with a semicolon. ${ }^{77}$

The notion that a government's inhumane acts against its own population may be punished even outside the context of a war relies on customary humanitarian law, rather than the law of war. ${ }^{78}$ The view that liability for crimes against humanity has an independent basis in humanitarian law is reflected in the practice of the Allied occupation authorities, and confirmed in United Nations resolutions. ${ }^{29}$ At least one commentator in-

74. Report of the International Law Commission to The General Assembly, 5 U.N. GAOR Supp. (No.12) at 11-14, U.N. Doc. A/1316 (1950).

75. Roeling, The Nuremberg and the Tokyo Trials in Retrospect, in 1 A TREATISE ON INTERNATIONal CRIminal Law supra note 70, at 590, 591-92; Levinson, Responsibility for Crimes of War, in War and Moral Responsibility (M. Cohen, T. Nagel \& T. Scanlon eds. 1974) 104, 115 n.; B. SMIrH, supra note 68, at 27,33; $c f$. Id. at 60 (arguing that concept of conspiracy brought atrocities committed against German subjects within ambit of war and, therefore, of war crimes).

76. London Agreement, supra note 60 , at 288.

77. See Finch, The Nuremberg Trial and International Law, 41 AM. J. INT'L L. 20, 22 (1947). By agreement of all the signatories, this decisive semicolon was later replaced with an ambiguous comma. See J. Oliver, N. Leech \& J. Sweeney, The International Legal System (1988) 794; Wright, The Law of the Nuremberg Trial, 41 AM. J. INr'L L. 38, 61 (1947) (asserting that the substitution of comma clearly excluded possibility that inhumane acts unconnected with war could be punishable).

78. International acceptance of the authority of a humanitarian law transcending the customs of war is evidenced by the oft-cited Preamble to the 4th Hague Convention, reading: "in cases not covered by the rules adopted by then, the inhabitants and the belligerents remain under the protection and governance of the principles of the law of nations, derived from the usages established among civilized peoples, from the laws of humanity, and from the dictates of public conscience." See Bierzanek, The Prosecution of War Crimes, I A Treatise on International Griminal Law supra note 70, at 559, 574 (noting influence of this text on Allies' conception of crimes against humanity); Meron, On the Inadequate Reach of Humanitarian and Human Rights Law and the Need for a New Instrument, 77 AM. J. INT'L L. 589 (1983) (Hague Preamble evidence of human rights foundation to the customary law of war); The Law of Land Warfare, U.S. Dept. of the Army Field Manual (FM 27-10) (1956) (As amended by change no. 1, 1976) (quoted in N. LeECH, J. SwEENEY \& C. Oliver, The International Legal System 761 (1988) (Hague Preamble evidence of binding authority of customary humanitarian law); Finch, The Nuremberg Trial and International Law, 41 AM. J. INT'L L. 20, 22-23 (1947) (crimes against humanity distinguishable from war crimes, on the basis of Hague Preamble and tradition of humanitarian intervention against government exterminations of their own subjects); and Levasseur, supra note 64, at 270-71 (1966) (increasing distinction between crimes against humanity and war crimes, growing out of tradition of humanitarian intervention).

79. Id. at 261-64, citing Allied Control Council Law no. 10, various judgments reported in The 
sists that it "undoubtedly" informed the French legislature's intentions in $1964 .^{80}$ Such efforts to detach crimes against humanity from the law of war have been criticized as entailing international interference in the internal affairs of sovereign states. ${ }^{81}$ But whether grounded in the law of war or humanitarian law, the French judiciary's claim that crimes against humanity are recognized by customary international law was aimed at denying their retroactivity.

Basing liability for crimes against humanity on customary international law also enabled France's highest court to wink at the irregularity of Barbie's arrest. Conforming neither to French nor Bolivian extradition procedures, Barbie's deportation from Bolivia to France was justified on the grounds that "because of their nature, crimes against humanity . . . do not come under French internal law only, but also under an international penal order to which the notion of boundaries and the extradition rules which ensue are fundamentally unknown." ${ }^{32}$ Hence, Barbie's irregular arrest was "in accordance with the general principles of law recognized by all nations." ${ }^{\text {"8s }}$ France justified this arrest on the same grounds on which Israel justified its abduction of Eichmann: the increasingly accepted claim that international law creates universal jurisdiction to pursue and prosecute criminals against humanity. ${ }^{84}$

By stressing the customary international law basis of Barbie's liability, the French judiciary was able to deny the retroactivity of his prosecution and the illegality of his arrest; but it was also forced to admit the universal applicability of imprescriptible criminal liability for crimes against humanity. The Treaty of London gave the Nuremberg Tribunal jurisdiction over crimes committed by agents of the Axis powers only. Because the London Agreement defined at least some crimes against humanity by reference to other crimes "within the jurisdiction of the Tribunal," one might argue that, by definition, crimes against humanity could be commit-

War Crimes Trial Law Reports, and General Assembly Resolution 95 of Dec. 11, 1946, supra note 71.

80. Id. at 280.

81. Schick, The Nuremberg Trial and the International Law of the Future, 41 AM. J. INT'L L. 770, 785-86 (1947). At least two responses have been advanced: (1) "since the destruction of . . . groups challenges civilization itself, it engages international interest." D. O'CONNELL, II INTERNATIONAL LAW 744 (1970). (2) crimes against humanity are creatures of international law because they concern the policies of states rather than individuals. Levasseur, supra note 64 . This latter argument for international supervision of municipal affairs finds expression in the French judiciary's conceptions of crimes against humanity as the product of a state policy or ideology. See infra text accompanying notes $96-108$.

82. Judgment of Oct. 6, 1983 Cass. crim. Fr. (No. 83-93.194 LEXIS) (quoting opinion of Office of Public Prosecutions with approval) (D. Bacardi, trans.) (on file with author)

83. Id.

84. See L. Henkin, R. Pugh, O. Schachter \& H. Smit, International Law, Cases and MATERIals 859 (1987) (Eichmann's charges included crimes against humanity); RESTATEMENT (Revised) of Foreign Relations Law of the United States, $§ 404$ (recognizing "universal jurisdiction" to "punish certain offenses recognized by the community of the nations as of universal concern such as . . . genocide [and] war crimes."); Judgment of Adolf Eichmann, 36 INT'L L. REP. 5 (1968) (universal jurisdiction justifies abduction). 
ted only by agents of the Axis powers. But because of the customary origins of crimes against humanity, the London Agreement has not been read this way. ${ }^{85}$

Accordingly, the invocation of the customary origins of the concept of crimes against humanity meant that such crimes could be committed by anyone, including French officials. This enabled Barbie's defense attorney, Jacques Vergès, to claim plausibly that French soldiers had committed crimes against humanity by killing and torturing Algerians, both combatants and noncombatants, during the Algerian Revolution. ${ }^{86}$ If French soldiers killed and tortured noncombatants during the Algerian Revolution, did they commit crimes against humanity as defined in customary international law? If liability for crimes against humanity is grounded in humanitarian law, then inhumane treatment of any civilian population is a crime against humanity. But if liability for crimes against humanity is grounded in the law of war, mistreatment of civilians only qualifies as a crime against humanity if it occurs in conjunction with a war.

Can a civil war like the Algerian Revolution be considered subject to "the laws and customs of war?"87 It can. The Geneva Convention Relative to the Protection of Civilian Persons in Time of War does not define "war crimes" as such, substituting the concept of "grave breaches,"88 which each signatory is obliged to prosecute. ${ }^{89}$ These "grave breaches" include the killing, torture, inhumane treatment, and unlawful deportation or confinement of "persons protected by this convention." of the convention defines noncombatants and prisoners taken in internal

85. Instead, "crimes within the jurisdiction of the Tribunal" is generally understood to refer to war crimes and crimes against peace. This reading is reflected in the International Law Commission's later formulation of "The Principles of Nuremberg," which defines crimes against humanity without reference to the Axis powers. Report of the International Law Commission U.N. GAOR V. Supp. 12, U.N. Doc. A/1316/14 14 (1950). Any reading of the Treaty of London's definition of crimes against humanity that separates the "inhumane acts" clause from the clause prohibiting "persecution . . . [in the course of] crimes within the jurisdiction of the Tribunal," is inconsistent with the claim that crimes against humanity can be committed only by agents of the Axis. See supra notes 76-77 and accompanying text.

86. See infra notes 239-48 and accompanying text. During much of the revolt, argued Vergès, the French government denied that the participants were belligerents, and falled to accord those arrested the protections accorded prisoners of war. Hence, even the combatants could be considered victims of crimes against humanity. See A. Benabdallah, M. Courrégé, M. Oussedik, J. Vergès \& M. Zavrian, Défense Politique 51-52 (1961) (all quotes, unless otherwise specified, translated by C. Bell \& G. Binder) [hereinafter DÉfEnse Politique]; $c f$. J. Bond, Rules of Riot: InTERnal. ConFLICT AND THE LAW OF WAR 114 (1974) (Red Cross construed French practice of interning suspected rebels in special camps rather than prisons as treatment "closely related" to that governing prisoners of war). As is typically the case during counterinsurgency, the lines between civilian and combatant victims is sometimes blurred. See, e.g., F. FANON, The WRETCHEd of THE EARTH 254-64 (1968) (descriptions of contexts of some atrocities committed in Algeria).

87. London Agreement, supra note 60 , at 288.

88. J. Pictet, Geneva Convention Relative to the Protection of Civilian Persons: COMMENTARY 597 (1958) ("grave breaches" chosen in preference to "war crimes" during drafting of Articles 146 and 147).

89. Id. (Art. 147).

90. Id. (Art. 146). 
conflicts as "protected persons" and specifically prohibits each of these forms of abuse, extending the customary law of war crimes to internal conflicts. ${ }^{91}$ Eventually, both sides in the Algerian dispute publicly accepted the applicability of Article 3 to the conflict. ${ }^{92}$ Even if the prohibition of crimes against humanity is a creature of the law of war only, that law applied to the Algerian dispute. Any inhumane treatment of civilians during the Algerian civil war would have constituted crimes against humanity. ${ }^{93}$ Any inhumane treatment of prisoners motivated by their race, religion, or political beliefs would also have constituted crimes against humanity.

This makes it especially embarrassing that France shirked the obligation imposed by the law of war to prosecute all "grave breaches" of it. In 1962 the French legislature granted French soliders amnesty for all "infractions" committed in combating the Algerian revolt. In 1964, days before declaring crimes against humanity imprescriptible, mutinous officers were excluded from this amnesty, but it was in other respects confirmed. In 1968, the amnesty was extended to the mutinous officers again. ${ }^{94}$ Each of these amnesty laws prescribed possible crimes against humanity, in seeming violation of the 1964 imprescriptibility statute, the London Agreement, and the principles of international law on which both were purportedly based. Because French law views treaties as superior to statutes, these amnesties appear illegal. ${ }^{95}$

This apparent prescription of crimes against humanity by the same legislature that declared crimes against humanity imprescriptible set a legal lacuna directly in the path of the Barbie prosecution. Thus, if they hoped to punish Barbie, French courts faced a painful choice. They could narrow the definition of "crimes against humanity," so as to distinguish some of Barbie's crimes from those commonly attributed to the French Army in Algeria. Alternatively, they could retain the London Agreement's broad

91. The fact that Art. 3 is the only conduct rule in the Convention governing treatment of prisoners and civilians in internal conflicts (see J. PICTET, supra note 88, at 34) does not remove it from the ambit of the enforcement rules in Articles 146 and 147. According to Pictet, Article 3 had roots in customary international law antedating World War II. Id. at 29-33. See also Meron, The Geneva Convention as Customary Law, 81 AM. J. INT'L LAw 348 (1987) (argument that the Geneva Convention should be viewed as declaratory of customary law of nations); Veuthey, Some Problems of Humanitarian Law in Noninternational Conflicts and Guerilla Warfare, in 1 A TREATISE OF International. Criminal Law, supra note 70, at 422-24; Tabenfeld, The Applicability of the Laws of War in Civil War, in LAw AND Civil. WAR IN THE MODERN WorLd 499 (J. Moore ed. 1974) (long scholarly tradition of support for application of laws of war to civil wars).

92. J. Bond, supra note 86 , at 60 .

93. Note that if the Algerian Revolution is not considered a war then even rebels must be considered civilians, protected by a humanitarian law conception of crimes against humanity.

94. 1962 J.O. (Fr.) 3144, Decree No. 62-328 (March 22, 1968) ("the infractions"); 1964 J.O. (Fr.) 11499, Law No. 64-1269 (Dec. 23, 1964) ("all infractions committed before March 20"); 1968 J.O. (Fr.) 7521, Law No. 68-697 (July 31, 1968) ("all infractions"). See Chronique, D.S. Jur. 21 (1968 LEXIS) (la notion de 'manquement a l'honneur, a la probité et aux bonnes moeurs) (discussion of periodic political amnesties in French law).

95. Judgment of Oct. 6, 1983, supra note 82 (superiority of conventional to statutory law). 
definition of imprescriptible "crimes against humanity" and lay the basis for an attack on the validity of the amnesty laws. Their choice of the first alternative would make the meaning of Nazism the central issue at Barbie's trial.

\section{2. "A Deliberate State-Controlled Policy"}

Shortly after his return to France, Barbie was charged with participation in eight "crimes against humanity," involving the deportation, shooting and torture of Jews and suspected Resisters. ${ }^{96}$ On July 20, 1985, however, Investigating Magistrate Christian Riss dropped all charges for crimes against suspected Resisters, retaining only the charges for deporting three groups of Jews: some ninety seized at a Jewish community center, about fifty discovered at a secret children's camp in Izieu, and over 300 sent from Lyons as the Germans withdrew. ${ }^{97}$

In upholding this decision, a Paris Court of Appeals defined crimes against humanity as "the persecution extending to the extermination, in peacetime as well as in wartime, . . . of any noncombatant because of their race or their religious or political beliefs in application of a deliberate state controlled policy, useless to the operations of war." the Court of Appeals narrowed the definition of crimes against humanity in three ways: 1) by conjoining the London Agreement's two disjunctive criteria, so that a crime was against humanity only if directed against a noncombatant and motivated by animus against the victim's origins or beliefs; 2) by requiring that this animus be expressed in a state policy, whereas the London agreement had recognized crimes against humanity committed against the perpetrator's own compatriots and contrary to the laws of the perpetrator's government; ${ }^{98}$ and 3 ) by requiring that the crime have no military utility.

For the Court of Appeals, the brutal suppression of a revolt merely involved illegal means to a legitimate end; by contrast, crimes against humanity required the illegal objective of gratifying hatred. Hence, the Court of Appeals characterized Barbie's suppression of the Resistance as

96. T. BOWER, supra note 18 , at 94,226 (detailing charges and their bases).

97. Riss also dropped several other charges for lack of evidence. Pretrial Probe of Nazi WarCriminal Completed, UPI, July 20, 1985 (LEXIS). The investigating Magistrate is distinct from the prosecuting attorney in France. C. PR. PEN. Fr. Art. 49 (1987). If the investigating magistrate determines that a charge is not supported by the facts, she must issue an order discontinuing the charges. Id. Art. 177.

98. Judgment of Dec. 20,1985, supra note 56. Appeals from an order of the Investigating Magistrate discontinuing charges may be brought be the Prosecuting Attorney, the Office of Public Prosecutions, and civil parties. C. PR. PEN. Fr. Art. 183, 186. The defendant may appeal orders requiring her pretrial detention or supervision and hence may challenge the legality of the charges continued by the Investigating Magistrate. Id., Art. 186.

99. German killings of German citizens on German soil would still be crimes against humanity even if "contrary to the laws of the country where committed." But c.f., Levasseur supra note 64, at 269-71 (arguing that only operation of state policy makes internal violence subject of international criminal law). 
one might easily characterize the French suppression of the Algerian revolt: as militarily useful mistreatment of combatants motivated by no official policy of racial, religious or political animus. ${ }^{100}$ The Court of Appeals had succeeded in rationalizing the amnesty of the French Army's Algerian indiscretions at the cost of extinguishing Barbie's liability for crimes against the Resistance.

Had this decision stood, Barbie's trial would have afforded its audience little opportunity for veneration of the French Resistance. Such a trial might not have involved any attempts to define Nazi ideology, although it would have included evidence of Germany's systematic policy of harming Jews. Had the French courts left out this requirement that crimes against humanity involve a state policy, the prosecution's case would have been complete upon a showing that Barbie killed or deported people merely because they were Jews. In short, had the French courts been willing to forego Barbie's prosecution for crimes against the Resistance, Barbie's trial might have occasioned no representations of Nazism.

\section{Ideological Hegemony}

But the Cour de Cassation refused this bargain: it insisted on distinguishing Barbie's repression of the Resistance from the French Army's repression of the Algerian revolution. France's high court did so by redefining crimes against humanity as "all inhuman acts and persecutions which, in the name of a state practicing a policy of ideological hegemony, have been committed systematically, not only against persons because of their membership in a racial or religious group, but also against opponents of this policy, whatever the form of their opposition." 101

Recall that the London Agreement deemed the execution of combatants to be a crime against humanity only if motivated by animus toward the victims' origins or beliefs, thereby involving "persecution." In the Barbie case, however, France's highest court expanded the class of potential victims of crimes against humanity to include any combatant "opposing" the persecution of others because of their origins or beliefs. This opposition, moreover, can take military form and need not involve any expression of opinion. By means of this decision, anyone killed for posing a military obstacle to the Nazi state has been transformed into a political martyr, a victim of persecution. Provided that a state "practices a policy of ideological hegemony," any soldier that the state kills on or off the field of battle becomes a victim of "crimes against humanity." On the basis of this definition, the Cour de Cassation quashed the Court of Appeals decision that had upheld the Investigating Magistrate's decision to drop all charges for

100. Id. Cf. DÉfense PolrtiQue, supra note 86, at 59-64 (characterizing French repression in Algeria as "genocide").

101. Judgment of Dec. 20, 1985, supra note 56. 
crimes against the Resistance. As a result Barbie was recharged for the deportation of more than 300 gentile Resistance suspects during 1943 and 1944 and the murder by torture of Jewish Resister Marcel Gompel. ${ }^{102}$

At least one commentator has hailed the Cour de Cassation decision as potentially covering atrocities against civilians "not because they are Jewish, partisans or political opponents but only because they belong to the enemy." 103 Under this interpretation, at least some of the atrocities committed by the French in Algeria would be crimes against humanity. But such an interpretation cannot be right. The opinion stresses that repressive measures against the Resistance constituted crimes against humanity because "they were presented, by those in whose name they were perpetrated, as politically justified by the national socialist ideology." 104 In applying this decision to reinstate charges for atrocities against the Resistance, a Paris Court of Appeals agreed that "the perpetrator of the crime against humanity should have acted within the framework of his affiliation with a policy of ideological hegemony such as the Third Reich's National Socialist ideology." ${ }^{105}$ While this appellate court dismissed the torture of Resisters as militarily rather than ideologically motivated, it viewed their deportation to death camps as an expression of "the Third Reich's policy of ideological hegemony." "106 In other words, Resisters were "persecuted" for their beliefs, as part of a systematic policy of exterminating those politically opposed to Nazi ideology.

For the French courts, "crimes against humanity" came to mean all and only crimes undertaken on behalf of a state committed to Nazi ideology. Hence, Barbie's prosecutors were required to identify the Nazi ideology his crimes enforced, and the ideals for which the Resistance was martyred and France liberated. ${ }^{107}$ And every noble ideal attributed to

102. The deportation accounted for two additional charges. The murder was a third. Gompel was skinned alive. See Id.; Miller, French Appeals Court Ruling Delays Barbie Trial, N.Y. Times, Dec. 21, 1985, § 1, at 4, col. 1; Theolleyre, Barbie to Face Three Charges of Crimes Against Humanity, Manchester Guardian Weekly, July 20, 1986, at 11.

103. A. CASSESE, supra note 28 , at 112.

104. Decision of Dec. 20,1985, supra note 56. The opinion apparently refers to the Court of Appeals" observation that Nazi propaganda characterized Resistance members as "judeo-Bolcheviks." Id. In a gloss on this case Judge Fernand Chapar (who was not involved in the decision) ruefully distinguishes Cassese's expansive conception of crimes against humanity from the court's. Chapar regrets that the opinion does not simply follow the London Agreement's definition of "crimes against humanity" and characterize the Resisters as victims because they were never recognized as belligerents "by the Germans, who should have, if they had recognized them as such, granted them the status of war prisoners." Annotation, D.S. Jur. 504 (Oct. 30, 1986). Of course this standard might also condemn the French of crimes against humanity for never granting arrested and tortured Algerians the status of war prisoners. See supra notes 86,92 and accompanying text. This sort of formal proof that victims of atrocity are necessarily civilians founders on the fact that torture and murder are inappropriate treatment for civilians as well as prisoners of war under the court's opinion. One could just as easily argue that Algerian and French Resisters must have been soldiers because their captors certainly didn't treat them like civilians.

105. Theolleyre, supra note 102 .

106. Id. The basis for this distinction between torture and deportation is that the torture was presumably motivated by the hope of eliciting information whereas the deportation appeared punitive.

107. Barbie's charges may be contrasted with the less ideologically focused charges he would have 
France in such a trial served to distinguish France's repression of Algeria as a mere crime of war because, after all, the French were not Nazis. ${ }^{108}$

The French judiciary required representations of the ideas embodied by Nazism and its victims as proof of Barbie's guilt. This Commentary's second Part interprets and critiques the prosecution's enthusiastic response to this doctrinal requirement.

\section{Prosecuting Nazism}

The French judiciary apparently hoped that the Barbie trial would illustrate French humanity by contrast to Nazi inhumanity. Accordingly, much of the prosecution's lengthy case consisted of testimony defining and explaining Nazism. "Crimes against humanity are committed after a plot and in this case stem from Nazi doctrine," explained Prosecutor Pierre Truche. ${ }^{109}$ "[These] witnesses will speak only of Nazi ideology." fense attorney Vergès protested to the court that "You are not here to condemn an ideology. The place for that is a political meeting. You are here to judge a man."111 Yet French officials proclaimed that the condemnation of Nazism was the principal purpose of Barbie's trial. ${ }^{\mathbf{1 2}}$ The ensuing analysis of the prosecution's condemnations of Nazism reveals the conflicting efforts of different groups to define themselves by contrast to Nazism. A subsequent critique of the use of war crimes trials to gain recognition for Judaism shows the futility of identifying oneself by one's enemies rather than one's own beliefs.

faced upon extradition to Germany. Like France, West Germany retroactively eliminated the statute of limitations for certain crimes in order to preserve liability for Nazi atrocities. STGB $\S 78$ (1980). See also Responses to World War II Criminals and Human Rights Violators: National and Comparative Perspectives, 8 Boston C. ThIRd World L.J. 3, 9 (1988) (remarks of G. Fletcher). Unlike France, however, Germany eschewed the Nuremberg Tribunal's "Crimes against Humanity" formula, instead preserving liability for ordinary murder, as well as genocide. The murder statute punishes deliberate or reckless killings motivated by cruelty, greed, lust or "other base motives." STGB $\$ 211$ (1980). The genocide statute, patterned on the International Convention on the Prevention and Punishment of the Crime of Genocide, G.A. Res. 260 (III)(A), U.N. Doc. A1810, at 174 (Dec. 9, 1948), 78 U.N.T.S., ratified by Federal Republic of Germany Nov. 24, 1954, 277, punishes killing, torturing, starving, forcibly converting, or preventing the birth of members of a national, racial or religious group with the intention of destroying that group. STGB $\S 220$ (1980). Hence a German trial of Barbie for complicity in the murder of suspected Resisters and Jews could have focused more narrowly on Barbie's state of mind, rather than Nazi ideology generally.

108. See Rosemberg, Barbie's Lauyer Accused of Trying to Put France on Trial, Reuters, June 24, 1987 (NEXIS) (Private prosecutor Nogueres distinguishes between crimes committed during occupations of France and Algeria).

109. Rosemberg, Barbie Trial Enters New Stage of Historical Testimony, Reuters, June 9, 1987 (NEXIS).

110. Id.

111. Id.

112. The Trial of Vichy France, The Economist, Feb. 12, 1983, at 55; Judge Refuses to Free Nazi War Criminal, AP, June 10, 1983, (NEXIS). 


\section{A. Conflicting Representations of Nazism}

\section{The Ambiguity of Uniqueness}

The prosecution insisted that Nazi crimes were unique. For many Frenchmen, the Nazis' uniquely systematic program of murder served to absolve France by comparison. Henri Nogueres, an attorney for the French Human Rights League, explained: "Crimes were perpetrated in Algeria, but not in the name of a state doctrine or of a monstrous system. They were war crimes, not crimes against humanity, and they took place in spite of a democracy we are proud of and not in its name as was the case in Nazi Germany."113 Veterans of the Resistance felt ennobled by the uniqueness of their enemy. "No matter how many traitors . . . were in the Resistance, it would still be a noble cause, because it was the resistance to Nazism," commented the socialist weekly, La Nouvel Observateur. ${ }^{114}$ For many French Jews, it was the Jewish identity of the victims that rendered Nazi crimes unique. According to Simone Weil, the trial's only important message could be that "millions . . . were exterminated, not because of what they did, but because of who they were."115 Prosecution witness Elie Wiesel felt that the suffering of the victims burdened their killers with unique guilt. No words could describe this "unparalleled tragedy," he said, and no punishment was adequate for these "crimes . . . of an absolute nature." "118

Thus the uniqueness of Nazi crimes could stand for either the compulsive efficiency of the Nazis or the concentrated agony of the Jews. As the prosecution's historical testimony unfolded, these two perspectives fused in an interpretation of Nazi crimes as the inevitable product of a racist ideology. Historian Leon Poliakov testified that extermination of Jews and Gypsies was essential to Nazism. "Only a pure race can master the earth," he quoted Hitler. ${ }^{117}$ "At Auschwitz we witnessed the systematic application of Hitler's racist doctrine, the doctrine according to which the Germans were a superior people with a mission to exterminate the others," added former Resistance leader Marie-Claude Vaillant Couturier. ${ }^{118}$ Such testimony fulfilled the hope of Lyon's Rabbi that the trial would "show where racism and intolerance can lead."119

113. Rosemberg, supra note 109. This view was supported by the socialist weekly Le Nouvel Observateur. See Rosemberg, Barbie's Trial Prompts French Soul-Searching, Reuters, May 17, 1987 (NEXIS).

114. Meisler, No 'Trial of Collaborators' Expected With Barbie Away from Court, L.A. Times, May 16, 1987, at I13, col. 1 .

115. Bernstein, Spirits Haunting a Belated Courtroom Reckoning, N.Y. Times, May, 18, 1987, at $\mathrm{A} 4$, col.3.

116. Rosemberg, Wiesel Addresses Barbie Trial, Clashes Erupt, Reuters, June 2, 1987 (NEXIS); Campbell, Barbie Said to Find Conviction 'Incredible', AP, July 4, 1987 (NEXIS).

117. Rosemberg, Barbie Trial Enters New Stage of Historical Testimony, supra note 109.

118. Rosemberg, Auschwitz Was Laboratory for Racial Purity Doctrine, Reuters, June 10, 1987 (NEXIS).

119. Bortin, One Year After Return Gestapo Chief Is No Closer to Trial, Reuters, Feb. 3, 1984 


\section{The Ambiguity of Racism}

But beneath the surface of these pieties controversy lurked. Racism by itself cannot explain Nazi crimes because, though always contemptible, racism does not generally lead to extermination. Even the Nazis, who viewed many races as inferior, targeted only the Jews and Gypsies for extermination. For many Jewish commentators, racism is too universal to explain the Holocaust; instead, it was the Nazi commitment to exterminate Jews that generated a justificatory racist ideology. ${ }^{120}$

On the other hand, for some of the witnesses, antisemitism was too particularized to explain the full range of Nazi crimes. Focusing on medical experimentation and slave labor, historian Genevieve De Gaulle suggested that scientific rationality and greed had produced the Nazi machinery of death. ${ }^{121}$ 'Racism' could explain Nazi crimes for so many people because of its indeterminacy. To some, it represented an antisemitism that threatened only Jews; to others, it stood for a social Darwinism that threatened the humanity of all.

These tensions became explicit when representatives of Jewish victims objected to the French judiciary's decision that Barbie could be charged with crimes against non-Jewish Resistance members. "We're confusing two different types of crimes," complained the President of Lyons' Jewish community. "Jews weren't opponents. They didn't fight."122 "There can be no comparison between the plight of the Resistance and the genocide of the Jews," agreed civil prosecutor George Bermann. ${ }^{123}$ Mixing the two, Simone Weil feared, would "trivialize the Holocaust," and "reduce" the Nazis' guilt. ${ }^{124}$

Resistance veterans saw this attitude as parochial. Confining Nazi guilt to Jewish victims, they felt, would reduce its global significance. "Nazi ideology was an attack on all humanity," insisted Resistance attorney Joe Nordmann. ${ }^{128}$ According to Nordmann, members of the Resistance were

(NEXIS). So strongly was racial prejudice identified with mass murder at the trial that civil prosecutor Sylvia Zimmerman pointed to the discriminatory Nuremberg laws as evidence that Barbie must have known of the impending extermination of the Jews, an argument that reflects poorly on those Jews who ignored such warning signs. Rosemberg, Nazi Horrors Aided by French Antisemitism, Lawyer Says, Reuters, June 19, 1987 (NEXIS).

120. See Y. Bauer, The Holocaust in Historical Perspective 35-36 (1978); Fackenheim, Foreword to Y. Bauer, The Jewish Emergence From Powerlessness at vii-ix (1979); Friedlaender, The Historical Significance of the Holocaust, 1 JERUSALEM Q. 36-59 (1976).

121. See Rosemberg, supra note 4; Rosemberg, supra note 118. De Gaulle is the niece of the General and Premier.

122. Echikson, French Ask Who Is on Trial: Barbie or Resistance?, Christian Sci. Monitor, May 28, 1987, at 9. This argument echoed those offered in the Court of Appeals decision that upheld the Investigating Magistrate's decision to discontinue the charges involving atrocities against Resisters. See supra text accompanying notes 98 \& 100.

123. Lyon, Reuters, May 9, 1987 (NEXIS).

124. Bernstein, supra note 115 .

125. Rosemberg, Nazi Horrors Aided by French Antisemitism, Lawyer Says, Reuters, June 19, 1987 (NEXIS). 
less soldiers than martyrs, persecuted for their anti-Nazi beliefs. ${ }^{126}$ For former Resistance leader Claude Bourdet, the Barbie prosecution represented a long awaited recognition of this martyrdom. "There's been a huge amount of propaganda over the past few years to convince people that only Jews were killed by the Nazis," Bourdet complained. ${ }^{127}$

\section{The Ambiguity of French Nationalism: Resistance or Nazism?}

Another dimension of controversy hidden by the representation of $\mathrm{Na}$ zism as racism concerned the degree of French complicity in Nazi crimes. Although antisemitism had long flourished in France, it had rarely been expressed in terms of the kind of systematic pseudo-science of race developed by the Nazis. ${ }^{128}$ Attorneys for the Jewish plaintiffs were insistent that the focus on Nazi ideology not obscure French complicity in the Holocaust. "By isolating . . . Jews," Vichy legislation "made it easy for the Germans to identify them," attorney Michel Zaoui recalled. ${ }^{129}$ "We are therefore entitled to ask that those Frenchmen who collaborated in this policy be also put on trial and convicted for crimes against humanity," added Alain Levy, attorney for a Jewish victim. ${ }^{130}$

Not surprisingly, the French government was less anxious to indict France. When Socialist President Mitterand and his Guevarist adviser Régis Debray brought Barbie from Bolivia, their aim was not to expose collaboration but to rekindle French identification with the predominantly leftist Resistance. Nevertheless, opposition politicians worried that the trial might provide an occasion for embarrassing the French right with charges of collaboration. ${ }^{131}$

Upon regaining control of the government in 1986, however, the conservative parties inherited the responsibility of prosecuting Barbie. ${ }^{\mathbf{1 3 2}}$ They responded by contending that the Resistance was not a leftist cause, but a French cause. The French showed "an increasingly strong and general opposition to the occupier," and "there were no traitors in the Resistance," testified the conservative National Assembly President, Jacques Chaban-Delmas. "133 "France will be acquitted before the tribunal of the

126. See Echikson, supra note 122.

127. Hotel Terminus, supra note 32.

128. See R. Rubenstein \& J. Roth, Approaches to Auschwitz 69, 182 (1987)

129. Theolleyre, Barbie Trial Hears Catalogue of French Antisemitism, Manchester Guardian Weekly, June 28, 1987, at 11.

130. Id.

131. See Mosby, Barbie, UPI, Feb. 8, 1983 (NEXIS) (statement of Francois Leotard).

132. The election of Mitterand in 1981 precipitated the formation of France's first left-wing cabinet in 23 years. In September 1983, however, a conservative coalition gained a majority in the Senate. In March of 1986, a similar coalition gained control of the National Assembly, requiring Mitterand to ask the conservative Jacques Chirac to form a cabinet, an anomalous situation described as "cohabitation." EuRoPA Y.B. 1034-35 (1988).

133. Rosemberg, French Need Not Blush Over War Record, Former Premier Says, Reuters, June 11, 1987 (NEXIS). 
world," the former Resistance leader predicted. ${ }^{134}$ The subtext was that because all French had resisted, the French left had no unique authority to represent France.

The ruling conservative coalition did not emerge from the Barbie trial unbesmirched, however. A week into the trial, Gaullist foreign trade minister Michel Noir precipitated a crisis by urging that the government repudiate the right-wing National Front party. Citing the National Front's racist rhetoric and opposition to North African immigration, Noir compared it to Nazism on Le Monde's front page. The lesson of the Barbie trial, he argued, was that the government should risk losing the next election rather than its "soul."135 This alarm over the growing influence of right-wing racism in French politics found expression in one civil prosecutor's summation, ${ }^{138}$ and in much of the trial's press coverage. ${ }^{137}$ Commenting on the trial, a conservative German daily warned readers, "The French susceptibility for leftist ideology disguises a tendency toward fascism that showed itself not only in the 1930's."138 In prosecuting Nazism, France's conservative government failed to exonerate itself before the tribunal of the world.

\section{Israel as Prosecutor}

France was not the only state that sought to justify itself by prosecuting Nazism at Barbie's trial. Claiming jurisdiction to prosecute Nazi crimes committed in any part of the world, the Israeli government first contemplated requesting Barbie's extradition and then offered to assist the French prosecution. ${ }^{139}$ Receiving no public response to this offer, Israel sent Ambassador Ovadiah Sofer to the trial during the summations. Speaking on the courthouse steps, Sofer told reporters that "terrorists are today's Nazis and SS. They create chaos and destabilize. They massacre non-combatants, preferably Jews, and innocent people, women and chil-

134. French Hope Barbie Trial Will Not Become Trial of Their History, UPI, May 12, 1987 (NEXIS).

135. Lewis, Barbie Is a Specter in a Cabinet Rift in France, N.Y. Times, May 20, 1987, at A11, col. 1 (late city final ed.). Noir's father was a concentration camp inmate.

Throughout 1987, Prime Minister Chirac attempted to unify his conservative coalition in anticipation of his 1988 campaign for presidency. In the month preceding Barbie's trial, Chirac's coalition introduced legislation eroding the right to citizenship of children of immigrants, in an effort to hold the nativist National Front in the coalition. In the two months following the trial, leaders of the Conservative coalition's two largest parties announced that they would not support Chirac's presidential campaign. EuROPA Y.B. 1035 (1988).

136. Rosemberg, Nazi Horrors Aided by French Antisemitism, Lawyer Says, Reuters, June 19, 1987 (NEXIS) (statement of Christian Charriere-Bournazel, attorney for Marcel Gompel's widow).

137. See, e.g., The Barbie Trial: Not Just Vengeance, N.Y. Times, May 14, 1987, at A30, col. 1 (late city final ed.); All our Barbies, The Economist, May 23, 1987, at 18.

138. McCartney, West Germans Note Barbie, Waldheim Forcing Others to Face Nazi Past, Wash. Post, May 23, 1987, at I-32 (quoting Die Welt).

139. Immanuel, Israelis Offer to Help Prosecute Barbie," AP, Feb. 6, 1983 (NEXIS) see supra note 84 (Israeli assertion of universal jurisdiction in Eichman judgment). 
dren. They dream, like the SS . . . of a world without justice, a world without liberty, a world enslaved."140

Such self-serving hyperbole is the unfortunate consequence of viewing Nazi crimes, not as a discrete set of historical circumstances in which Klaus Barbie played a role, but as an ideology which Barbie merely represented.

\section{B. Nazi Crimes and Jewish Identity}

\section{What's Wrong with Representing Nazism}

The images of Nazism offered by Barbie's prosecutors distorted the complex causation of crimes committed in the name of Nazism. These crimes were made possible by the convergence of ideology, expedience, technology, bureaucracy, economic depression, and the immigration policies of many nations. ${ }^{\mathbf{1 4 1}}$ The attribution of Nazi crimes to an ideology marshals eleven million dead for and against ideas that could never, by themselves, have killed or saved anyone. In addition, the prosecution of Nazi ideology attributes more consistency to Nazi thought and Nazi purposes than may be appropriate. The less confidence people feel in the coherence of their own purposes and principles, the more they may be tempted to identify themselves by contrast to a Nazi ideology they see as easily defined and totally evil. The irony is that Nazism provided an identity for many confused and rootless Germans only by attributing a similarly malignant coherence of purpose to Jews. ${ }^{\mathbf{1 4 2}}$ Where once Nazis sought solidarity in the suppression of an imagined Jewish conspiracy, contemporary Jews are tempted to build their communities on the condemnation of remembered Nazi atrocity. This subsection argues that this development is unfortunate.

Self-definitions derived principally from the conduct of an oppressor do

140. Israeli Ambassador Compares Nazi to Terrorists, UPI, June 22, 1987 (NEXIS).

141. An emerging view among Holocaust historians is that the no single cause can explain the Holocaust. Diverse, inconsistent and opportunistic, Nazi ideology appeared in response to the socioeconomic crises of the interwar years and developed in dialectical interaction with the vagaries of politics and war. Arno Mayer has recently argued that antisemitism assumed central importance in Nazi ideology, shouldering aside antimarxism, only with the Nazi rise to power. Richard Rubenstein and John Roth have stressed that antisemitism has often led to persecution and expulsion of Jews without yielding systematic extermination. Both studies agree that Nazi antisemitism initially took this form; that the unwillingness of Western governments to accept Jewish refugees, whether caused by antisemitism or economic depression, helped route Nazi policy toward "the final solution;" and that the route was paved by the same "advances" in technology and bureaucracy that mobilized other wartime powers. Mayer adds that the German defeat on the Eastern front sped Jews toward their fate. See generally A. Mayer, Why Did the Heavens Not Darken? The Final Solution in History (1988); R. RubENStein \& J. Roth, APPRonches to Auschwitz (1987).

142. See A. MAYER, supra note 141, at 92-109 (identifying social origins of German Fascism among economically displaced petty bourgeoisie; describing efforts of Nazi propagandists to provide lower middle class with collective identity defined in opposition to a single enemy; describing Hitler's strategy of attributing inconsistent qualities to that enemy, while stressing the enemy group's solidarity and racial purity). 
not articulate for what the self stands. In representing themselves primarily as victims, people affirm no distinctive ethos of their own. At the same time they appear to envy the oppressor for having an identifying ethos, even if that ethos is wrong. Hence a disturbing element of self-contempt can be found in identities defined by contrast to Nazism. Too often, representations of Nazism are constructed to support representations of self that are self-effacing and hence also self-defeating.

The futility of efforts to define Judaism by reference to Nazism illustrates this problem. Deriving Jewish identity from the Holocaust effaces Jewish particularity by assimilating Judaism to the sacrificial symbolism of Christianity. The following discussion suggests that international war crimes prosecutions are too embedded in the universalistic values of Christianity to permit the assertion of Jewish identity. It proceeds to criticize the highly influential Holocaust theology of prosecution witness Elie Wiesel for encouraging Jews to mourn Jewish identity as a casualty of the Holocaust. It concludes with a warning that Holocaust-centered conceptions of Jewish identity can impoverish Jewish ethical life by reducing it to the single dimension of survival. In sum, this subsection argues that Jews should not use the prosecution of Nazi war crimes as an occasion for defining group identity. Stressing Jewish victimhood neither gives voice to Jewish particularity nor provides Jewish communities with ethical guidance.

\section{Jewish Victims, Christian Symbols}

A sacrificial culture assigns God a voracious appetite for violence that can only be sated as the result of a trick, a substitution. In the judicial culture formed by God's covenant with Abraham it is human sacrifice-a slaughter of the innocent, compounded by deceit-that is the ultimate crime. $^{143}$

Christian culture is organized around the sacrificial symbolism of the Crucifixion. Seeing an infinite disjunction between the human world of symbols and the divine world of meanings, Christianity despairs of humanity's capacity to justify itself before God. Hence it can only be redeemed as a result of a sacrificial substitution. ${ }^{144}$

But Jewish culture is judicial rather than sacrificial. Seeing divine ordinance as fully expressed in scripture, Judaism sees human obligation as rigorous, but finite. Seeing each individual as capable of justifying herself

143. See generally R. GiRARd, Violence and The SACREd 1-38 (P. Gregory trans. 1972) (distinction between sacrificial and judicial culture). From Girard's essentially Christian persepctive, all culture is fundamentally sacrificial and deceitful. Judicial culture is doubly deceitful because it hides its truly sacrificial nature. See J. Culler, ON Deconstruction 29 (1982) (characterization of Girard as Christian religious thinker).

144. GIRARD, supra note 143, at 259 (necessity of sacrifice for salvation); see also O. PATTERson, Slavery and Social Death 70-71 (1982) (divine sacrifice redeems Christians from slavery to $\sin )$. 
before God, it rejects sacrifice as unnecessary. Judaism believes that God does not suffer by being nailed down in writing. Accordingly, the transubstantiation of Jewish victims into sacrificial symbols is at odds with Jewish culture.

As a result, the Barbie trial's controversy between Jewish survivors and Resistance veterans over Nazism's meaning reflects a deeper conflict of cultures that makes the Nazi war crimes trial an inhospitable forum for the definition of Jewish identity.

The Barbie trial's symbolism was more sacrificial than judicial. The prosecutors often emphasized the victims' innocence more than the defendant's guilt-hence the insistence of Jewish groups that the Jews alone did not resist, countered by the claims of Resistance veterans that their comrades were persecuted for their beliefs rather than their actions. By claiming the millions as martyrs, these groups interpreted the Holocaust as the vast sacrifice that would finally redeem the world from violence. The Barbie trial was a dramatic reenactment of the Holocaust in which the dead died, not in vain, but for our moral instruction. ${ }^{148}$ From a Christian perspective, this use of the dead as a sacrifical symbol may be legitimate; but Jews should greet this redemption of irredeemable suffering with ambivalence.

Jews have sought vigorous prosecution of Nazi war crimes as an affirmation that Ghristian civilization has finally repudiated antisemitism. Yet Christians can repudiate antisemitism simply by being too polite to notice that anyone is a Jew. Jews have therefore insisted on acceptance of the Holocaust as a uniquely Jewish experience, in the hope that Christian civilization would reject antisemitism while also valuing Jewish particularity. Identifying value with universality, ${ }^{146}$ however, Christian civilization values particulars only as symbols with universal significance. Such a culture can only respond to Jewish demands for recognition by transforming the Jew from universal scapegoat to universal martyr. Hence Jews cannot accept the recognition offered them by Christian civilization without sacrificing their particularity.

This was the issue underlying the Barbie trial's debate over what distinguished Nazi crimes as unique. Many observers-Jewish and gentile-have offered explanations of Nazi crimes that assimilate them to other events in human history. Accordingly, the Nazis' mass murder has

145. Michael Berenbaum argues that sacrificial themes are implicit in the guilt-ridden veneration of the victims found in much Jewish response to the Holocaust. See M. BERENBaUM, Vision of THE VOID (1979). See also A. MAYER, supra note 141, at 16 (term "Holocaust" denotes sacrificial offering; criticizes "cult of remembrance"). For an example of a sacrifical theology of the Holocaust, see $I$. Maybaum, The Face of God AfTer Auschwitz (1965).

146. See J. Pocock, Politics, Language and Time 80-82 (1971) (tension between exclusive value of universal in medieval Christian thought and need to explain particular events); see also A. Lovejoy, The Great Chain of Being (1936) (tension between exclusive value of the abstract in Western civilization, and belief in divine creation of worldly particulars). 
been variously attributed to monopoly capitalism, ${ }^{147}$ "totalitarian" bureaucracy, ${ }^{148}$ lawlessness, ${ }^{149}$ phobic anti-communism, ${ }^{150}$ sexual repression, ${ }^{151}$ racism, ${ }^{162}$ nationalism, ${ }^{163}$ and paganism. ${ }^{154}$ Other scholars-primarily, but not exclusively, Jewish-have responded that the murder of six million Jews, although carried out alongside the murder of five million gentiles, is historically unique. Signifying this uniqueness by the term "Holocaust," these scholars generally argue that no other religious or ethnic group has ever been targeted for total and unconditional extermination. Hence these "Holocaust" interpreters distinguish Nazi crimes on the basis of both the identity of the victims and the methods and motives of the perpetrators. ${ }^{185}$

Who is the audience for this claim of uniqueness, and what is its meaning? The claim of uniqueness is directed to gentiles and implies the authority of the universalistic values it appears to challenge. The insistence that the Holocaust is unique implies that it was not only different from other suffering, but more significant. ${ }^{188}$ Now for Jews the Holocaust is of unique importance, not because it was unlike other suffering, but simply because it happened to Jews. The claim that the Holocaust is objectively unique has a wider audience: It is designed to interest the gentile world in Jewish suffering. If the Holocaust is objectively unique, then its unique significance is universally recognizable. Seen in ths light, the Holocaust becomes a uniquely accessible emblem of Judaism, because appreciating its Jewishness does not depend upon identifying as a Jew. Accordingly, the claim of objective uniqueness denies that there is a uniquely Jewish perspective from which the Holocaust is especially meaningful.

This convergence of uniqueness and universality is implicit in the Nuremberg Tribunal's characterization of the Holocaust as a "crime against humanity." This novel formulation establishes retroactive liability, often

147. See F. Neumann, Behemoth: The Structure and Practice of National Socialism (2d ed. 1944).

148. H. Arendt, The Origins of Totalitarianism (1966); R. Hilberg, The Destruction OF THE EUROPEAN JEWS (1985).

149. G. Kren \& L. Rappoport, The Holocaust and the Crisis of Human Behavior (1981); Fuller, Positivism and Fidelity to Law-A Reply to Professor Hart, 71 HARv. L. REv. 630 (1958); Lewis, Foreign Affairs: A Model of French Justice, N.Y. Times, July 6, 1987, at 31, col. 1 (late city final ed.).

150. E. Nolte, Three faces of Fascism (1966).

151. W. REICH, THE MASS PSYCHOLOGY OF FASCISM (1970).

152. S. Chorover, From Gensesis to Genocide (1979); R. Lifton, The Nazi Doctors: Medical Killing and the Psychology of Genocide (1986).

153. L. KRIEGER, THE GERMAN IDEA OF FreEdoM (1957).

154. E. Rosenstock-Huessy, The Christian Future 73, 160 (1966).

155. E. FACKENHEIM, THE JeWISH RETURN INTO HISTORY: REFLECTIONS IN THE AGE OF Auschwitz AND A NEw Jerusalem (1978); Friedlaender, On the Possibility of the Holocaust, in The Holocaust IN Historical Perspective (Y. Bauer, ed 1978); Eckhardt \& Eckhardt, The Holocaust and the Enigma of Uniqueness, 450 ANNALS 165 (1980). See A. MAYER, supra note 141, at 15-17 (describing and criticizing conception of historical "uniqueness" and sacrificial symbolism implicit in use of term "Holocaust").

156. Wyschogrod, Faith and the Holocaust, 26 JUDAISM 286, 292 (1977). 
justified on the grounds that Nazi crimes were unprecedented. ${ }^{157}$ Like the victims, jurisdiction to prosecute crimes against humanity wanders across borders, uniquely ubiquitous, uniquely homeless. A crime against humanity harms a victim because of her unique origins or beliefs; yet the interest harmed is always the victim's universality, her "humanity." According to the Nuremberg formula, when a Jew is killed because of her Jewishness, it is not her Jewishness that is attacked. To the contrary, it is this excessive attention to her Jewishness that dehumanizes her. In short, to view her as nothing more than a Jew is to see her as less than human. ${ }^{158}$

Constrained by its own universalistic morality from recognizing the uniqueness of Nazism's victims, Western culture has understood Jews to be making a claim for the extremity of their suffering. Such a claim commands attention because all suffering has universal significance in Christianity. No longer persecuted for killing Christ, the Jew may now find a place in Christian culture as a Christ symbol in whose death every Christian dies and is reborn. ${ }^{158}$

It would be unfair to expect Christian culture to interpret the Holocaust outside of a Christian framework of values and symbols. But it is important for Jews to remember that international war crimes trials are addressed to gentiles and framed by Christian culture. When Jews identify themselves in terms of the suffering imposed upon Jews by gentiles, they give up just what identifies them as Jewish. "A theology of suffering, endemic to other religious traditions, is foreign to Judaism," argues Deborah Lipstadt in criticizing what some see as an overemphasis of the Holocaust in American Jewish life. ${ }^{160}$ Sacrificial symbolism represents Jewish particularity in terms that efface it.

Why then has the Holocaust become the basic token of Jewish identity in the postwar world? When that world reassures Jews that they are no different from anybody else, they are tempted to insist that they cannot help being different, that persecution has made them different. Behind this pose of frustrated assimilationist lies the anxiety that assimilation is already an accomplished fact, the fear that the Holocaust annihilated not only Jews, but the Jewish world. If Jews bitterly embrace the Holocaust

157. Ryu \& Silving, International Criminal Law-A Search for Meaning, in 1 A Treatise on International Griminal LAw, supra note 70, at 22, 27-28; Tornaritis, The Individual as a Subject of International Law and Intermational Criminal Responsibility, id. at 103, 108.

158. By contrast to the Nuremberg and Barbie trials, Eichman was charged not only with "crimes against humanity," but also with "crimes against the Jewish People." Nazi Collaborators (Punishment) Law (5710-1950, No. 64, 4 Laws of the State of Israel 154). The Eichman judgment, however, characterized "crimes against the Jewish people" as "the gravest type of "crime against humanity." 1 A TREatise on INTERnational CRiminal Law, supra note 70, at 528 (quoting judgment).

159. Representations of the Jewish victim in American popular culture have sometimes suggested that the real suffering of the Jews lies in an inability to accept spiritual rebirth as Christians. See Avisar, Christian Ideology and Jewish Genocide in American Holocaust Movies, in 3 Holocaust Studies AnNual 21-42 (1985) (discussion of The Mortal Storm).

160. Lipstadt, Invoking the Holocaust, 30 JUDAISM 335, 339 (1981); see also Alter, Deformations of the Holocaust, Commentary, Feb. 1981, at 48. 
as an identity, that may be because, in its own wake, the Holocaust is the only specific Jewish legacy left to them. ${ }^{161}$ This contradiction lies at the heart of the Holocaust theology promoted by star prosecution witness Elie Wiesel.

\section{Judaism as Witness: The Holocaust Theology of Elie Wiesel}

No one has stressed the perils of representing the Holocaust more than survivor and author Elie Wiesel:; ${ }^{162}$ and yet, for many, no one represents the Holocaust more than Wiesel. Wiesel accepts this total identification with the Holocaust, referring to his tortured memory as "my entire being, what I am." "18s Memory of the dead weighs upon him so heavily that Wiesel can identify little of himself as his own. In one of Wiesel's novels, a survivor describes the possession of his soul by the memory of the dead:

' $I$ ' had remained over there in the kingdom of night, a prisoner of the dead. The living person . . . I thought myself to be . . . was nothing more than an echo of voices long since extinguished, nothing more than a shadow stumbling against other shadows whom I was cheating and betraying day after day, as I forged ahead. I thought I was living my own life, I was only inventing it. ${ }^{164}$

Haunted by memory, Wiesel views his own survival as deceitful, his actual life as a novelist as invented, his literary inventions as not his own, but merely the voices of the dead. ${ }^{165}$

Wiesel's modesty by no means diminishes the powerful presence of his personality in his writing. Wiesel endures little loss of identity in subordinating himself to his characters because everyone recognizes that his abdication of authorship is part of the fiction. Hence his self-effacement is an authentic expression of identity precisely because it is his own literary invention. Wiesel's selflessness is a fictional character, but also a signature, a nom de plume.

Unfortunately, Wiesel imposes this self-effacing identity on other Jews. Wiesel's studied humility has gained him enormous authority within the Jewish community to tell others how to identify as Jews; and what he tells them is that they too must be occupied by the memory of the dead. According to Wiesel, all Jews are identified by memory: "If we stop remembering, we stop being." ${ }^{\text {"168 }}$ Memory of the Holocaust, in particular, is

161. I take it as an example of the difficulty of asserting Jewish identity in a universalistic culture shared by Jews and gentiles alike, that I have been persuaded to refer to Jews as "they" rather than "we" throughout this Commentary, lest the readers of this Journal be misled into believing that they are all Jewish.

162. E. WIEsel, A Plea for the Survivors, in A JEW Today (1978).

163. 1 E. WIESEL, supra note 1 , at 239.

164. E. Wiesel, A Beggar in Jerusalem 159-60 (1970).

165. See 2 E. WIESEL, supra note 1, at 117-18.

166. Id. at 368 . 
crucial to Jewish identity: "No Jew can be fully Jewish today . . . without being part of the Holocaust."18z Thus, Wiesel represented the Holocaust at the Barbie trial because "to be a Jew today . . . is to testify."168 Accordingly, Wiesel insists that the burden of incarnating the dead is not his alone: "All Jews are survivors."168

Wiesel's identification of Judaism with the memory of the Holocaust explains his enigmatic statement at the Barbie trial that he testified to "prevent the killer from killing a second time."170 Certainly he wished to prevent the Nazis from compounding their crime by denying that any crime occurred. ${ }^{171}$ And certainly he wished to keep the dead alive in memory. But in so doing he also sought to preserve the living as Jews. Inspired by Wiesel, the influential Jewish theologian Emil Fackenheim has claimed that the memory of Auschwitz forbids us from "handing Hitler any more posthumous victories" by abandoning Judaism. ${ }^{172}$ But for Wiesel, Judaism cannot be removed from the Eastern European milieu in which it flourished and died before his eyes. Perhaps convinced that Jewish identity cannot survive the destruction of these traditional communities, Wiesel sees the memory of that destruction as the postwar Jew's only link to Judaism. Defining Judaism as the memory of Auschwitz, Wiesel seeks to preserve Judaism by embalming living Jews with the identities of the dead.

Wiesel's necrolatry is a response to this sense that the Holocaust threatened not only Jews, but the validity of Judaism. The most memorable passage in Wiesel's writing, describing his first encounter with the crematoria, is punctuated by this lament: "Never shall I forget those flames which consumed my faith forever."173

Auschwitz could consume Wiesel's faith in God because it evidenced God's infidelity to the Jewish people. The God worshipped by the Jews of Eastern Europe operated in history under obligations defined by the covenant with His chosen people. In that covenant He promised to protect them in return for faith and obedience-but to punish them harshly for disobedience or infidelity. The orthodox theological response to persecution and suffering among Jews was therefore to see it as punishment for

167. Id. at 252.

168. E. Wiesel, One Generation After 24 (1970).

169. 2 E. WIESEL, supta note 1 , at 305.

170. Rosemberg, Wiesel Addresses Barbie Trial, Clashes Erupt, Reuters, June 2, 1987 (NEXIS).

171. Wiesel Sees Holocaust Coverup, UPI, June 3, 1987 (NEXIS). Wiesel referred at the Barbie trial to neo-Nazi "historians" who argue not only that no Jews were gassed, but that most of those killed never existed. See, e.g., A. Butz, HoAx of the Twentieth CENTURy (1976); P. RAŚsinier, Debunking the Genocide Myth (1978).

172. E. FaCKENHEIM, supra note 155, at v, 4 (influence of Wiesel acknowledged).

173. E. Wiesel, Night 4 (1969). 
deviation that would be removed and redeemed by greater religious commitment. ${ }^{174}$

For Wiesel, however, the Holocaust cannot be accounted for within this covenantal orthodoxy. No Jewish sin could possibly justify the magnitude of the punishment and no future bounty could possibly redeem it. God's apparent willingness to dispense with His people showed not anger, but indifference. Thus, as far as Wiesel is concerned, if God exists, He has broken the covenant binding the Jews to him. ${ }^{175}$

Faced with God's infidelity, the controversial theologian Richard Rubenstein has decreed that after the Holocaust we live in a time of the death of God, in which the Jewish religion is of questionable relevance. ${ }^{176}$ Despite his acknowledgment that Auschwitz consumed his faith, Wiesel has rejected Rubenstein's approach, because, with Emil Fackenheim, he feels that to abandon Judaism is to betray the dead. Rather than abandoning Judaism, Wiesel substitutes the Holocaust for God as the focus of Jewish identity. ${ }^{177}$

In Wiesel's liturgy, the Holocaust takes on some of the traditional attributes of God. "Auschwitz is . . the end of creation. Its mystery is doomed to stay whole, inviolate."178 Holocaust victims, in particular, have replaced God as inexpressably sacred. Accordingly, despite the Jewish obligation to testify about persecution, it is blasphemy to discuss the victims. ${ }^{178}$ In Wiesel's play, The Trial of God, a pogrom survivor is not afraid to name God as the author of Jewish suffering, yet he refuses to name the daughter whose torture he helplessly witnessed. ${ }^{180}$ Wiesel preserves the covenantal framework by substituting Holocaust victims for God as the Jewish people's covenantal partner. ${ }^{181}$

Thus, Wiesel replaces a God who can be satisfied by righteous action with human victims whose suffering Jews can never redeem or live up to. Yet gentiles, outside of the covenant, can be redeemed by Jewish suffering: "If we wish to save the world it can only be by opening this secret and painful door to our common memory," Wiesel testified at the trial. ${ }^{182}$ Hence, Jewish identity consists in having endured persecution in order to

174. R. RuBENSTEIN \& J. Roth, supra note 141 , at 301.

175. Wiesel, Jewish Values in the Post-Holocaust Future, 16 JuDAISM 281-85 (1967). See generally M. BERENBAUM, supra note 188, at 152-80 (1979) (analysis of Wiesel's response to this problem).

176. See generally R. Rubenstein, After Auschwrrz (1966); RubENSTEIN \& Roth, supra note 141, at 308-16; M. BERENBAUM, supra note 145 , at 160-71.

177. See I. Abrahamson, Introduction Essay, in Against Srlence: The Vorce and Vision of ELIE WIESEL (Wiesel measures everything, including God, against Holocaust).

178. E. WIESEL, supra note 162 , at 198 .

179. Id. at 189-93, 186-87, 197, 204.

180. E. Wiesel, The Trial of God 44 (1979).

181. See M. BerEnbaum, supra note 145 , at $127,157-58$ (for Wiesel, memory of dead replaces God as partner in covenant).

182. Rosemberg, supra note 170. 
teach the persecutors a lesson. ${ }^{183}$ Wiesel asks Jews to accept the identity persecution has inscribed upon their people's tombstone in hopes that humanity will accept this memorial as the tablet of its law. The difficulty is that such an identity violates Wiesel's own injunction against letting the enemies of Judaism define it. ${ }^{184}$ If Jews can no longer believe they were chosen by God, must they value their selection by Hitler? In Wiesel's Holocaust theology, Jewish identity is represented by the annihilation of Jews. This sacrificial identity is also a sacrifice of identity, which is why Holocaust theology can seem so appealing. It is tempting for Jews to view their particularity as imposed by persecution because that relieves them of the burden of imposing it upon themselves. Defining themselves as sacrificial victims can win Jews a place in Christian culture as objects of pity, as Christians unredeemed by grace. But in return they give up the ethical obligations of Judaism. Renting Shoah, ${ }^{185}$ they can suffer safely in their living rooms, and learn that after the Holocaust one need do nothing to remain a Jew.

\section{The Political Context of Holocaust Judaism}

The Holocaust became the focus of American Jewish identity after the Six Day War of June 1967. The "miraculous" Israeli victory in the face of what many Jews perceived as a renewed threat of extermination inspired the influential Holocaust theology of Emil Fackenheim, an accelerating interest in Holocaust education, and eventually, the formation of the United States Holocaust Memorial Council, with Wiesel at its head. ${ }^{\mathbf{1 8 6}}$ Thus interest in the Holocaust arose already embedded in what theologian Jacob Neusner has called "the Myth of Holocaust and Redemption," in which Israel is valued both as a lesson learned from the Holocaust and as a guarantee against its future repetition. ${ }^{187}$ For American Jews, the 1967 war dramatized this myth because it seemed to replay the Holocaust with a different ending. ${ }^{188}$

Richard Rubenstein claimed before the Six Day War that American Jews could not confront the Holocaust without risking their identity and

183. E. WiESEL, supra note 162, at 182-83 (in killing all Jews, Christians kill Christ and endanger themselves).

184. "[T] Je Jew can only be defined in his relationship to himself. Subject and not object, he is an end in himself, and not a function of what rejects him or of what he is not." "Lamont, Elie Wiesel; In Search of a Tongue in Confronting THE HoLOcaust 96-97 (A. Rosenfeld \& I. Greenberg eds. 1978) (quoting Wiesel); see also E. WIESEL, supra note 1, at 297.

185. Shoah (Paramount Home Video, 1985).

186. J. Neusner, Stranger at Home: "The Holocaust," Zionism, and American JudaISM (1981); 1 E. WIESEL, supra note 1, at 149-95.

187. J. NEUSNER, supra note 186 , at 1 .

188. See E. Fackenhem, supra note 155, at 108-09, 130; E. Wiesel, A Beggar IN JerusaLEM 244 (1970) (expressing this sentiment); cf. B. Avishar, THE TragedY of Zionism 350-53 (1985) (noting and criticizing this sentiment). 
faith. ${ }^{189}$ Yet the Holocaust became a central symbol of Jewish identity after Israeli conquest had purged its memory of the shame of victimhood and the threat of extermination. With victory, the Holocaust became a useful justification for the morally uncomfortable position of occupier in which Israel found itself. In addition, victory popularized the "lesson" that Jews must do whatever is necessary to ensure their survival, lest they "hand Hitler posthumous victories."180

This lesson impoverishes Jewish politics. Israel is a Jewish polity, the very purpose of which is to discriminate on the basis of religion in composing its membership. ${ }^{191}$ Holocaust Judaism teaches that such a state is necessary to insure that Jews will always have a refuge from antisemitism. The difficulty is that Holocaust Judaism provides no compelling reason to be Jewish. If Jews can escape persecution by assimilating-by escaping Judaism-then they need no such refuge. Only if there is some distinctive ethical value to Judaism is it morally imperative that Jews be guaranteed survival as a culture and community.

In the covenantal tradition, ethical obligation has been central to Jewish identity, albeit coupled with a faith that God would reward compliance by making the Jews a great nation. That the Holocaust indicates God's absence from history need not release Jews from their commitment to pursue righteousness. Instead, the Jewish community can carry out both sides of the covenant, claiming the obligation to define Jewish values

189. R. RUBENSTEIN, supra note 176.

190. E. FACKENHEIM, supra note 155 , at 4.

191. Israel's Declaration of Independence characterizes Israel as "the Jewish state in Eretz Yisrael, which would open wide the gates of the homeland to every Jew and confer upon the Jewish people the status of a fully privileged member of the comity of nations. . . The State of Israel will be open for Jewish immigration and for the Ingathering of the Exiles." B. AvishaI, supra note 188, at 178 (quoting Israeli Declaration of Independence). The Israeli Knesset established no constitution upon its founding, but passed a series of basic laws that continued the Jewish Agency's policies of favoring Jewish settlement, including The Law of Return, conferring citizenship on any Jew desiring to immigrate, and The Law of Lands of Israel, forbidding the alienation of public land to any gentile. Id. at 187-89. Nevertheless, Bernard Avishai has offered a subtle argument that Israel need not be conceived as essentially discriminatory, or even Zionist. Avishai's overall argument is that Zionism was a transitional movement aimed at establishing a Jewish cultural and political community in Palestine for a variety of reasons. A state was neither necessary nor sufficient for this goal. Once established, such a community has a right to self-determination that can find expression in a state, but no more so than Arab communities. And the resulting states need not discriminate. Avishai points to the claim in the Declaration of Independence that Israel will "ensure the complete equality of social and political rights to all its inhabitants irrespective of religion, race, or sex; it will guarantee freedom of religion, conscience, language, education and culture ... it will be faithful to the principles of the Charter of the United Nations," id. at 178, and notes the tension between these rights and the charactcrization of Israel as a Jewish state. Id. at 184. He stresses the tolerant, democratic ideals of the cultural Zionist and labor Zionist currents that he views as the mainstream of the movement up to Israel's founding, id. at 23,49-98, while acknowledging that labor Zionist support for unrestricted residence in Palestine was premised on the expectation that it would ultimately lead to a Jewish majority. Id. at 92 . He argues that since Israel adopted no constitution, the institutionalization of preindependence discrimination need not be viewed as constitutive of Israel's identity, and notes that the constitutional language proposed upon independence would have forbade such discrimination in the name of Jewish values. Id. at 184-89. Further complicating the issue it should be noted that the Israeli Declaration of Independence also invokes the Holocaust as a justification for establishing a Jewish state. 
and realize them in history as its own rather than God's. Unlike Holocaust Judaism, a conception of Judaism as a distinctive nomos can justify Judaism's realization in an intrinsically Jewish polity. But such a polity would be constrained to preserve its utopian purpose as well as its people. By contrast, the interpretation of the Holocaust as the justification for Israel debases both. The myth of "Holocaust and Redemption" insults the dead and corrupts the living, because no compensation is sufficient to rectify the Holocaust. It reassures Israelis, and teaches Palestinians, that past oppression justifies future oppression. Jewish values antedate the Holocaust, and a major goal of Zionism was to create a self-determining political community in which those values could be realized independent of European oppression. ${ }^{192}$ Jews did not need the Holocaust to learn neighborliness, nor does the Holocaust justify them in forgetting it.

Accordingly, Israel does not realize its purpose merely by surviving, nor does a single-minded devotion to Jewish survival ensure the survival of Jewish values. If anything, the devotion of Jews to community has sometimes militated against individual survival, leading to the accusation that Jewish victims have passively accepted persecution. ${ }^{193}$ Before Barbie's trial, one journalist charged that the children of Izieu could have been saved had they been dispersed in Christian homes instead of housed conspicuously together. ${ }^{194}$ Such accusations ignore the courage of Jews determined to share the fate of their families and communities. ${ }^{105}$ Consider the halting trial testimony of Leah Feldblum, who taught at Izieu because "I have always taken care of children." 196 She accompanied the children to the camps where "they burned them all," she recalled. "Two of them I took by the hand, the sky was red, it was night . . . the children were frightened." ${ }^{197}$ Armed with false identity papers, she could have passed as a gentile, and so escaped: "I don't want to make myself out like a heroine, but I loved. . . . A three year old child came up to me. . . I I am a kindergarten teacher. . . . So I said to the man. . . . I am Leah Feldblum!'198 This was no act of martyrdom, but a simple expression of self. She did not adopt this identity out of defiance, nor, when it proved costly

192. For the range of utopian visions of Jewish community that found expression in Zionism, see

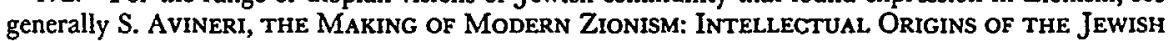
State (1981); B. Avishai, supta note 188; J. Frankel, Prophecy and Politics: Socialism, Nationalism and the Russian Jews $1862-1917$ (1981); A. Hertzberg, The Zionist Idea (1959); N. Levin, "While Messiah Tarried": Jewish Socialist Movements 1871-1917 (1977).

193. H. ARendt, Eichman in Jerusalem: A Report on the Banality of Evil 111 (1963) (wartime Jewish leaders eased Nazi's task by allowing Jews to be ghettoized).

194. Meisler, Letters From Jewish Children May Return to Haunt 'Butcher of Lyon,' L.A. Times, Jan. 20, 1985, at 16 (home ed.) (quoting Maurice Rajsfus).

195. See Y. Bauer, The Jewish Emergence from Powerlessness (1979).

196. Ophuls, Klaus Barbie's Circus of Evil, 244 The Natron 884, 886 (1987).

197. Id.

198. Id. 
to her survival, did she give it up. Leah Feldblum needed no Holocaust to know who she was.

\section{Representing Occupation}

Like ancient religious traditions, revolutionary movements lose their moral bearings when they identify themselves in terms of their enemies. The advocacy of Barbie's radical defense attorney Jacques Vergès can be criticized on these grounds. By condemning colonialism and Nazism as equally reprehensible, Vergès misrepresented Barbie; but by cynically dismissing all politics as hypocrisy, Vergès also misrepresented the national liberation movements for which he purported to speak. National liberation movements cannot credibly object to foreign domination without identifying some values as authentically their own.

\section{A. Representing a Nazi}

\section{The Fugitive Client}

Vergès easily displaced his client as the trial's chief villain. Figuratively, Barbie remained a fugitive even after his arrest. Realizing that his accusers would not condemn him without defining him, Barbie resisted identification: "The word Nazi doesn't exist," he told an interviewer on the plane to France. "Can you tell me what is a Nazi?"198 Nazism, Barbie seemed to feel, was too profound to be discussed before an unsophisticated audience. "Just what are the ideals you feel were betrayed?" asked Judge Cerdini at the trial. ${ }^{200}$ "If Herr President wants to discuss these issues with me personally, I am of course at his disposal," replied Barbie courteously, "but I must warn him that it will take a little time. I can't be expected to deliver a lecture here on National Socialism."201 Barbie seemed determined not to reveal himself. The only explanation he would ever offer the court for his activity in Lyons was that "At the time I had hierarchical chiefs and I did my duty under the orders of my superiors." ${ }^{202}$ Barbie then announced his intention of boycotting the trial, in terms that also portrayed him as an object acted upon by others: "If I find myself here today it is because I have been illegally expelled. . . . It is therefore up to my lawyer to defend me. . . . The trial may follow its course. The witnesses may come. But I shall not be present. . . . I will be represented by my lawyer."203 Thereafter, for most observers, Nazism was represented by Barbie's controversial attorney, Jacques Vergès.

199. Hotel Terminus, supra note 32.

200. Ophuls, supra note 196.

201. Id.

202. Rosemberg, Barbie Walks Out of Nazi War Crime Trial, Says He's Kidnap Victim, Reuters, May 14, 1987 (NEXIS).

203. $I d$. 


\section{Vergès as Nazi}

A Resistance veteran and avowed anticolonialist, Vergès shocked France by undertaking the defense of a Nazi. Vergès attributes his anticolonialism and antiracism to his origins: his father lost a promising career in the French diplomatic service as a result of marrying Vergès' Vietnamese mother. A Resistance fighter and Communist Party official in his youth, Vergès first came to public notice for his defense of Algerian rebels. Marrying one of these clients, Vergès took the surname "Mansour" and embraced Islam. He later edited a Maoist journal that published some of Régis Debray's Bolivian dispatches. Vergès defended a number of Palestinians accused of terrorism, before mysteriously disappearing for most of the 1970s. ${ }^{204}$

The author of several books on the political role of the criminal defense attorney, ${ }^{208}$ Vergès is known for his effective use of the media as a forum for his controversial clients' views. Because of this reputation, an angry public interpreted Vergès' decision to defend Barbie as an endorsement of Barbie's political views. Some ominously noted Vergès' youthful friendship with Pol Pot, perhaps attributing to him a catholic taste in mass murderers. ${ }^{208}$ Others associated his anti-Zionism with antisemitism, or speculated that his fee was paid by a pro-Nazi financier. ${ }^{207}$ Interpreting Marcel Ophuls' film on Barbie, The New York Times' James Markham wrote: "The cigar-puffing Mr. Vergès . . makes the point for Mr. Ophuls that the extreme of Nazism and anti-semitism comes full circle and touches the other extreme of anti-colonial leftism."208 Finally, some saw signs of Nazism in Vergès' tactics and demeanor. The Resistance leader Raymond Aubrac, arrested with Jean Moulin, thought Vergès "a good lawyer for Barbie. . . they share the same behavior and philosophy." 200 Civil prosecutor Serge Klarsfeld was "delighted that Barbie's lawyer speaks. . . his client's language."210

What prosecutors found truly annoying, however, was that Vergès did not resist their condemnation of Nazism. Instead, he deployed his client's authority as a Nazi in support of his own definition of Nazism. According

204. T. Bower, supra note 18, at 229-30; A. CASSESE, supra note 162, at 113; Rosemberg, Barbie's Lawyer, From Guerilla Gun-Running to Nazi's Defence, Reuters, May 11, 1987 (NEXIS); Andriotikis, In France, When a Terrorist Needs a Lawyer, Jacques Vergès Usually Gets the Call, People, March 9, 1987, at 109 (NEXIS).

205. Défense Politique, supra note 86; J. Vergìs, De la Strategie Judiciare (1968); J. Vergès, Pour en Finir Avec Ponce Pilate (1983) [hereinafter Pilate].

206. Rosemberg, supra note 204; Holland, Jacques Vergès: Barbie's Lawyer is a Mystery Man, UPI, May 13, 1987 (NEXIS).

207. MacIver and Lewis, Standing up for Barbie, Maclean's, May 25, 1987, at 41 (paraphrasing Serge Klarsfeld and philosopher Bernard Henry-Levy); A. CASSESE, supra note 28, at 115 (speculation that Vergès' fee was paid by allegedly pro-Nazi Francois Genoud).

208. J. Markham, Marcel Ophuls on Barbie; Reopening Wounds of War, N.Y. Times, Oct. 2, 1988 , at 21 , col. 1 (late city final ed.).

209. Holland, Defense Witnesses Appear, UPI, June 15, 1987 (NEXIS).

210. T. Bower, supra note 18 , at 230 . 
to Vergès, Nazism was an example of Western imperialism, accepted by France during the Occupation and replicated by France during its Algerian and Vietnamese wars.

\section{Vergès as Ironist}

Vergès' political agenda did not prevent him from playing his role as defense attorney by raising doubts about the prosecution's procedure and evidence. Yet even these seemingly routine arguments were couched in terms that suggested Western complicity in or recapitulation of Nazi crimes. In denying that Barbie had participated in the Final Solution, for example, Vergès noted the embarrassing failure of French prosecutors to charge him with any killings or deportations of Jews at his earlier trials. ${ }^{211}$ This could not be taken seriously as evidence of Barbie's innocence, but it suggested French indifference toward the fate of the Jews.

This point was underscored by another of Barbie's evidentiary arguments. One of the prosecution's most important pieces of evidence was a telex, sent by Barbie, reporting the Izieu roundup to his superiors. A copy of this telex was presented by the French prosecutor at Nuremberg in 1946. Yet in preparing Barbie's previous prosecutions the French government had ignored this damning evidence of Barbie's complicity in the extermination of Jews. ${ }^{212}$ Vergès sought to have the telex excluded as a forgery. While admitting its probable authenticity, he argued that anyone might have typed Barbie's name onto it. ${ }^{213}$

Vergès persisted in claiming that the telex had been fabricated even after Serge Klarsfeld discovered the copy bearing Barbie's original signature, ${ }^{214}$ prompting one of the trial's strangest incidents. As the telex was being passed among the attorneys, Judge Cerdini asked Vergés to remove its plastic cover. Klarsfeld immediately lept to his feet to protest Vergès' being permitted to handle the precious document. "I don't have 'dirty hands," " quipped Vergès, in reference to Sartre's play about collaboration of the same title. ${ }^{216}$ "I didn't say that your own hands were stained," responded a confused Klarsfeld. "But with you, words always have a different meaning." ${ }^{218}$ And Vergès' words did have a "different" meaning. His purpose in constantly harping on the telex was not to discredit it, to efface or besmirch it, as Klarsfeld feared. It was not Vergès, after all,

211. Ulbrich, Prosecutors Seek to Make Barbie Trial a Condemnation of Nazism, AP, Apr. 25, 1987 (NEXIS).

212. T. Bower, supra note 18, at 166; see supra notes 35,56 and accompanying text (discussing previous trials).

213. Morgan, Voices from the Barbie Trial, N.Y. Times, Aug. 2 1987, $\S 6$, at 20, col. 1 (NEXIS); J. Vergès, La Face Cachée Du Procìs Barbie 19 (1983).

214. Nazi Hunter Klarsfeld Says He Has Found Important Document, AP, Feb. 17, 1987 (NEXIS); Holland, supra note 209; Bernstein, supra note 7.

215. J. Sartre, Dirty Hands, in Three Plays (L. Abel, trans. 1949).

216. Bernstein, supra note 115; Morgan, supra note 213. 
whom the telex accused, but the French who had failed to prosecute Barbie for the crime the telex reported:

Vergès further shamed the prosecution on this score with a deft procedural argument. Shortly after the trial commenced, Vergès asked the court to dismiss all the charges on the grounds of double jeopardy, urging that the 1954 verdict of the military tribunal was so vague that it "covered the entire criminal operation of the SD of Lyons." ${ }^{\text {"217 }}$ In response, state prosecutor Pierre Truche was forced to argue that the two previous convictions were "only for the facts we were aware of," implying that the Izieu deportation was unknown at the time. ${ }^{218}$ Vergès placed him in the dilemma of either conceding the double jeopardy argument or acknowledging postwar France's indifference to crimes against the Jews.

Other technical arguments enabled Vergès to liken any informality or inconsistency in Barbie's prosecution to Nazi lawlessness. Arguing that Barbie's deportation from Bolivia to France was not in accord with forms of extradition recognized in French law, Vergès said, "Fighting Nazism with the methods of Nazis only gives Hitler a posthumous victory."219 Vergès framed his argument that Barbie's prosecution was unconstitutionally retroactive in similar terms. ${ }^{220}$ At the trial, Vergès characterized such retroactive liability as reflecting "Nazi-like thinking."221

Like Vergès' claim that the telex was forged, his references to the "Nazi-like" retroactivity of the prosecution had a "different," or ironic meaning. This is revealed in a published defense of his decision to accept the Barbie case. ${ }^{222}$ In this work, Vergès argues that the legislature could not have intended the law of $1964^{223}$ to establish or extend liability retroactively for crimes against humanity because that would have subjected French army officers to liability for committing atrocities during the Algerian revolution. ${ }^{224}$ Here the irony of Vergès' position emerges-he is characterizing the French state as Nazi-like, not for prosecuting Barbie retroactively, but for failing to retroactively prosecute its own officers. ${ }^{225}$

217. Judgment of June 3, 1988, Cass. Crim. Fr. (No. 87-84.240, LEXIS) (D. Bacardi trans.) (quoting Vergès) (on file with author); Rosemberg, Barbie Denied He Masterminded Persecution of Jews, Reuters, May 12, 1987 (NEXIS).

218. Id.

219. Nazi War Criminal's Lawyer Plans Bolivian Trip, AP, June 19, 1983 (NEXIS). Investigating Magistrate Christian Riss denied a petition for release relying on this argument shortly after his arrest. See Judge Refuses To Free Nazi War Criminal, AP, June 10, 1983 (NEXIS). Vergès' arguments were ultimately rejected by the Cour de Cassation, see supra note 82 and accompanying text. Nevertheless, Vergès repeated in his summation that the "extradition" of Barbie was "in the tradition of Berlin." Holland, Barbie, UPI, July 2, 1987 (NEXIS).

220. See supra text accompanying notes 65-67.

221. Meisler, French Accused of Nazi-like Thinking for Prosecuting Barbie, L.A. Times, July 3, $1987, \S 1$, at 6 , col. 1 (home ed.).

222. J. VERGÈs, supra note 213, at 13 (associating retroactivity with repressions of Vichy regime).

223. See supra notes $64-81$ and accompanying text.

224. J. VERGÈs, supra note 213 , at $35-36$.

225. Such prosecution would have enabled the French state to "authoritatively disavow" the 
Vergès' evidentiary and technical arguments were servants of his rhetorical strategy. The goals of that strategy were to link the two themes of collaboration and colonialism in recent French history.

\section{Vergès as Provocateur}

The first step in Vergès' program of accusing France was the publication of a book, in the fall of 1983, which claimed that Moulin was betrayed to Barbie as the result of an elaborate conspiracy. ${ }^{226}$ The charge that treachery was widespread among the upper echelons of the Resistance, from which postwar France drew its leadership, stirred controversy and created apprehension that Barbie might substantiate or even expand Vergès' charges at his trial. ${ }^{227}$ Hence it generated a wider audience for Barbie's trial while deflecting attention from his crimes. If France was interested in Barbie primarily because of Moulin, they would be promised a real show. Vergès suggested that the government might delay the trial indefinitely for fear of what Barbie would reveal concerning Moulin's fate. 228

But preventing a trial was far from Vergès' purpose. He wanted a trial, not to vindicate Barbie, but as a forum for his own views. On the eve of the trial, Vergès was still promising a trial that would once and for all destroy the myth that "the entire nation had fought to rout the occupation."229 Yet Vergès could not have intended to keep this promise. Even before Vergès took over the case, it appeared that Barbie actually remembered little about the events of that time. ${ }^{230}$ By February of 1983, it was already clear that Moulin's death would not be among the crimes against humanity charged to Barbie. ${ }^{231}$ Moreover, before the trial, Resistance leaders accused by Vergès won libel judgments against Vergès and another proponent of his conspiracy theory. ${ }^{232}$

atrocities that Vergès sought to characterize as Nazi-like. See J. FeInBERg, Doing AND Deserving 5 (1970) on this and other symbolic uses of punishment.

226. According to Vergès' account, Combat, one of the Resistance forces, was taking money and orders from the American OSS (Office of Strategic Services), against De Gaulle's wishes. Moulin, as De Gaulle's representative, attempted to put a stop to this, earning the enmity of Combat's leadership. Believing that Rene Hardy had become Barbie's agent, they nevertheless insisted that he be allowed to attend the "secret" meeting at which Moulin was captured by Barbie. Vergès also implicates Raymond Aubrac, who attended the meeting for the Liberation group and was later freed by his wife in a daring rescue. He supplies no motive for this alleged treachery, however. PILATE, supra note 205, at 25-38.

227. Bell, French Resistance Hero Betrayed by Comrades, Lawyer Says, Reuters, Nov. 13, 1983 (NEXIS); French Scorn Allegations That Resistance Hero Was Betrayed, Reuters, Nov. 14, 1983 (NEXIS); Ulbrich, The Trial of Klaus Barbie Is Not the Trial of a Man, AP, Dec. 10, 1983 (NEXIS).

228. Meisler, supra note 221.

229. Rosemberg, Trial to Focus on Collaboration With Nazis, Lawyer Says, Reuters, April 30, 1987 (NEXIS).

230. T. Bower, supra note 18 , at 226 .

231. See id. at 2.

232. See Judgment of Oct. 22, 1985, Bull Civ. I, Fr. (No. 4711 A/M LEXIS). 
When Barbie announced his decision to boycott the trial, it became clear that no revelations would come from his lips. While Vergès expressed disappointment in Barbie's decision, it seems likely that Vergès instigated it. ${ }^{233}$ Other clients have cleared the field for Vergès by absenting themselves from their own trials, notably Lebanese guerrilla Georges Ibrahim Abdallah; ${ }^{234}$ and in an early work on political trials, Vergès quoted Lenin's advice that it is sometimes better to "boycott the tribunal."238

Judge Cerdini prevented Vergès from cross-examining prosecution witnesses on the Moulin affair. ${ }^{236}$ Vergès acquiesced, and offered no testimony to support his conspiracy theory. ${ }^{237}$ Vergès' summation accused Jewish leaders deported by Barbie to their deaths of collaboration, ${ }^{238}$ but said nothing about Resistance complicity in Moulin's capture. To a great extent, Vergès' controversial charges against the Resistance proved to be part of a bait-and-switch strategy. Once he had attracted his audience, he wanted to talk about something else.

\section{Vergès as Prosecutor}

What Vergès wanted to shift the world's attention to was the criminality of colonialism. "France officially had 200,000 deaths during the German occupation for 40 million inhabitants. Algeria had during the French repression one million deaths for nine million inhabitants," Vergès told the press as the trial opened. ${ }^{239}$ Initially, Vergès presented French colonial repression as a natural extension of French collaboration in Nazi repression: "The French officials of today are attempting to make us believe that barbarity stopped in 1945, and that they ended it," he explained. "I do not want to allow this." ${ }^{240}$ If French leaders could collaborate in atrocities against their own citizens, why would they shrink from atrocity against their colonial subjects?

Ultimately, however, Vergès needed the French public to maintain its

233. Rosemberg, supra note 202.

234. Rodriguez, Guerrilla Suspect Quits Trial After Tirade Against France, U.S., Reuters, Feb. 23, 1987 (NEXIS).

235. Défense Politique, supta note 86 , at 64.

236. Cerdini's rationale was that the Moulin affair was the subject of a separate civil suit pending against Barbie. See Barbie's Judge Deflects Testimony of French Collaboration, UPI, June 12, 1987 (NEXIS).

237. The only witness Vergès called who had personal knowledge of the Moulin affair was the hostile Raymond Aubrac. Rosemberg, Barbie Lawyer in Tactics Switch, Judge Halts Anti-French Attack, Reuters, June 16, 1987 (NEXIS).

238. Meisler, supra note 221. Hannah Arendt made a similar charge in the wake of Eichmann's trial. See H. ARENDT, supra note 193, at 111 (1963).

239. Holland, supra note 209. Undoubtedly many of the Jewish civil plaintiffs felt that Vergès was making the wrong comparison in counting France's entire population. One-third of the quarter million Jews in France in 1940 were killed, two-thirds of the nine million Jews of Europe.

240. Bortin, One year After Return, Gestapo Chief is No Closer to Trial, Reuters, Feb. 3, 1984 (NEXIS). 
reverence for the Resistance, because his condemnation of French colonialism turned on an analogy between the French Resistance and the Algerian resistance. "I don't see how the French government can give amnesty for crimes against humanity committed in Algeria . . . by French officers," Vergès argued, "and at the same time declare that crimes against humanity committed by German officers in France are not subject to the statute of limitations." 241 If one equates German crimes with the Final Solution, Vergès' question is easily answered: The French army, like most of history's brutes, only killed whomever they could not control, whereas the Germans preferred murder to domination. Vergès' analogy between France's Occupation and Algeria's, therefore, turned on highlighting the martyrdom of the Resistance and obscuring the annihilation of the Jews. Seen in this light, the Nazis were imperialists and their great crime was the brutal suppression of a struggle for national self-determination. And seen in this light, removed from its context within the Final Solution, France's ordeal was mild compared to Algeria's.

For Vergès to offer his analogy of Nazism and French colonialism at the Barbie trial, it was crucial that Barbie be perceived primarily as an opponent of the Resistance. This was a principal reason why the defense kept the public's attention focused on Barbie's role in the Moulin affair until the last minute. This also helps explain another curious decision on the part of Vergès: When a Paris appeals court expanded Barbie's charges to include atrocities against Resistance members in July of 1986, Vergès declined to appeal. ${ }^{242}$ Vergès wanted Barbie charged with crimes against the French Resistance so that he could charge France with crimes against Algerian revolutionaries.

In pursuit of this goal, Vergès brought suit against the French government on behalf of relatives of two Algerians allegedly tortured to death by French troops. ${ }^{243}$ Predictably, the suit was dismissed on the grounds that atrocities committed during the Algerian revolution were covered by an amnesty. Vergès then called one of the Algerian plaintiffs as a defense witness at the Barbie trial to make his point concerning the inconsistency of French law. ${ }^{244}$ Vergès called additional witnesses to testify in support of his analogy between atrocities in occupied France and in colonized Algeria, but their testimony was severely truncated by Judge Cerdini. ${ }^{245}$

Unrestricted by Cerdini during his summation, Vergès ignored the

241. Ulbrich, supra note 211.

242. Theolleyre, supra note 102. Probably there was little to be gained by appealing, however, given that the appeals court had followed the guidance of the Cour de Cassation in its Judgment of Dec. 20,1985, supra note 56. One might even argue that the appeals court did not broaden the charges as much as the higher court might have wished.

243. Rodriguez, Barbie's Lawyer wants Mitterand Adviser to Testify, Reuters, May 7, 1987 (NEXIS); Bernstein, Six Witnesses Take the Stand in Barbie's Defense, N.Y. Times, June 16, 1987, at $\mathrm{A} 13$, col. 1 (city ed.).

244. Id.

245. Holland, Defense Witnesses Appear, UPI, June 15, 1987 (NEXIS). 
Moulin affair and concentrated on the Algerian uprising. "Do crimes against humanity only merit the name when they are committed against Europeans?" he asked. ${ }^{246}$ Beginning with a symbolic "bow" to the children of Izieu, he recalled Africans killed by the Nazis in the defense of France and compared them to Algerian World War II veterans killed by the French during the Algerian revolution: "Is it also in their names that you are going to judge Barbie?"247 Concluding with a description of the massacre of 15,000 Algerians in the town of Setif, Vergès asked, "Why would some ... be the touching victims of crimes against humanity, while others fall into anonymity, victims of regrettable mistakes?"248

Vergès' efforts to deflect the Court's attention onto the sufferings of the Third World were broadened by the summations of two colleagues. Apartheid, argued Congolese attorney Jean-Martin M'Bemba, "is the most virulent form of Nazism today." ${ }^{248}$ Algerian lawyer Nabil Bouaita attributed what he called "Palestinian genocide" to the "Nazification of the Jewish-Israeli people." Repeating an analogy introduced by Vergès in cross-examining Wiesel, Bouaita condemned Israel's 1982 invasion of Lebanon as a holocaust: "There is no difference between the man who lights the fire in the crematorium and the pilot who pushes the button to release an incendiary bomb. Is it by this derisory difference that civilization is measured?"250

\section{The Prosecution of Vergès}

For the attorneys representing Barbie's Jewish victims, Bouaita's summation was the last straw. Already anxious that the prosecution of Barbie's crimes against the Resistance might deflect attention from his role in the Holocaust, ${ }^{251}$ they found Vergès' comparison between Nazism and colonialism "an insupportable insult."252 But where the identification of colonialism with Nazism merely dispossessed Jews of the Holocaust, the identification of Israel with Nazism seemed to turn the Holocaust against Jews. "This is extremely grave and intolerable," shouted Jewish victims' attorney Michel Zaoui, unleashing pandemonium in the courtroom. ${ }^{253}$ The following day leaders of Lyons' Jewish community

246. Higgins, Defense Challenges France's Right to Try Former Nazi Barbie, Reuters, July 1, 1987 (NEXIS); Cody, 3rd World Invoked in Barbie Trial; Crimes Continuing Says Defense Team, Wash. Post, July 2, 1987, at A23, col. 1 (final ed.).

247. Id.

248. Id.

249. Higgins, Barbie Trial Disrupted as Tempers Flare During Defense Plea, Reuters, July 1, 1987 (NEXIS); Rosemberg, Barbie's New African Lawyer Says Nazi Crimes Like Colonialism, Reuters, June 18, 1987 (NEXIS).

250. Holland, Barbie, UPI, July 2, 1987 (NEXIS); Higgins, supra note 246; Rosemberg, Wiesel Addresses Barbie Trial: Clashes Erupt, Reuters, June 2, 1987 (NEXIS).

251. Lyon, Reuters, May 9, 1987 (NEXIS).

252. Holland, supra note 245 (quating Charles Kormann).

253. Higgins, supra note 246. 
threatened to swear out a complaint against Bouaita for the crime of "promoting racial hatred."254

Even those attorneys and observers who did not regard Vergès' rhetorical strategy as an insult, dismissed it as a smokescreen. "The defense is going to talk about things Barbie is not charged with in order to cause distraction," warned Charles Libman, one of the civil prosecutors. ${ }^{255}$ Before Vergès presented his case, State Prosecutor Pierre Truche warned the jury that the defense attorney would ignore the case against his client. Instead, protested Truche, Vergès would attempt a "defense by deviation," that would "displace the focus of this trial."258 Agreeing that Vergès' case against colonialism and Zionism was irrelevant, Judge Cerdini prevented Vergès from putting it before the jury. ${ }^{25 z}$

Vergès' analogies between Nazism, colonialism and Zionism may well have been offensive. But the charge that they were irrelevant was hypocritical. Vergès was criticized for offering three witnesses who claimed no knowledge of Barbie's actions during the war. Yet the prosecution offered "scores" of witnesses with no such knowledge. ${ }^{268}$ Vergès' arguments concerned the meaning of Nazism, which was, after all, the central issue addressed by the prosecution and its legion of expert witnesses.

Consider the irate Michel Zaoui's own summation, during which he chastised Vergès for spreading "rumors" about collaboration and colonialist crimes. "The Jews also were the butt of rumors that they wanted to rule the world with their greed for profit," he told the jury. "Your condemnation of Barbie will serve as a rampart against such rumors, based on lies and inexactitude. . . we must preserve the memory of what took place for this memory can serve to prevent evil."259 If Vergès' analogy between colonial massacres and the Holocaust is hyperbolic, how much more so is Zaoui's analogy between Vergès' innuendo and the Holocaust? If Vergès demanded an acquittal because of the alleged crimes of the prosecuting state, Zaoui demanded a conviction because of the alleged Nazism of the defense attorney. Vergès equated any unjust killing with Nazism while Zaoui equated any false witness with Nazism. Each was guilty of exploiting and trivializing Nazi crimes for his own rhetorical purposes;

254. Holland, supra note 250.

255. Ulbrich, supra note 211.

256. Rosemberg, Prosecutor Attacks Barbie's Lauyer for Sidestepping at Trial, Reuters, June 15,1987 (NEXIS).

257. To some observers, Vergès' analogies between Nazi crimes and other wrongs missed the whole point of a criminal prosecution. "The tactic," explained survivor and stateswoman Simone Weil, "is to show that everything that ever happened . . . is the same. Everybody is guilty, so nobody is guilty." Bernstein, supra note 115. "It's an entirely crazy proposition," argued former Resistance leader Claude Bourdet. "If you read it this way, you could never have any trial against any criminal, anywhere." Holland, supra note 250 .

258. See Rosemberg, supra note 256.

259. Rosemberg, Nazi Horrors Aided by French Antisemitism, Lawyer Says, Reuters, June 19, 1987 (NEXIS). 
but because Zaoui's purpose was to bear false witness against Vergès, he was guilty, in addition, of hypocrisy.

\section{B. Representation as Occupation}

The prosecution's complaint that Vergès distracted attention from the trial's legal issues must be dismissed as hypocritical. This subsection argues that Vergès is more justly criticized on his own terms, as a political advocate for anticolonial resistance. Vergès' highly publicized characterization of the French Resistance as a sham exemplified cynical assumptions that cast doubt on the authenticity of anticolonialist resistance as well. Vergès' decision to represent a Nazi reflects this disillusionment: unable to respect the authenticity of his clients, he now occupies his clients for purposes that are not their own. Worse still, Vergès subordinates his clients to values in which even he no longer believes.

\section{Authenticity and Occupation}

The Occupation was a galvanizing period that brought together the intellectual currents of existentialism and Marxism. Prewar existentialists, like postwar Jews, were disillusioned theists in search of a civil religion. ${ }^{260}$ Political values were already embedded in their disillusionment with Christianity, because institutional French Catholicism was traditionally antirepublican and antisemitic. ${ }^{261}$ Nevertheless, prewar existentialists were without a politics of their own. They responded to the sanctimonious pieties of the French right by adopting a politically empty posture of nihilism. Existentialists inhabited a godless cosmos which could only be given normative meaning by an act of human will. Accordingly, left-leaning existentialists needed a cause for their political instincts to be transformed into the commitments that could structure a moral universe. ${ }^{262}$

The Occupation provided this opportunity. Joining the beleaguered communists in their self-defense, existentialists began to find in Marxism a civil religion that could justify sacrifice. ${ }^{203}$ An impotent fringe before the war, France's intellectual left found itself, at war's end, perhaps the only political force in France untainted by collaboration. ${ }^{264}$

The strange result is that there are two quite different stories that one can tell about this period. One emphasizes the political identity of postwar France with the Resistance. This is a story of courage and commitment, of the triumph of unambiguous good over clear evil. In such a context, one need only respond "authentically" to one's feelings of right and

260. Wiesel was especially influenced by Camus. Lamont, Elie Wiesel; In Search of a Tongue, in Confronting The Holocaust 88-96 (A. Rosenfeld \& I. Greenberg eds. 1978).

261. R. Rubenstein \& J. Roth, supra note 141, at 69-70, 74-77.

262. W. BarretT, IRRATIONAL MAN 239-41 (1962) (quoting at length from J. Sartre).

263. M. Poster, Existential Marxism in Postwar France 75-79, 109 (1975).

264. Id. at $36-38$. 
wrong to have clean hands. ${ }^{286}$ The authentic patriot, then, was the rare individual who preserved the autonomy of her moral judgment against foreign occupation. During the Occupation, such heroic individuals were able to find moral absolutes in a godless world. Because this story presents individuals and groups as creators of meaning, it exemplifies the "humanism" often attributed to the existential Marxists. ${ }^{266}$

The other story emphasizes the political identity of wartime France with the collaborationist Vichy regime. If one emphasizes the ubiquity of collaboration, one tells a story of small souls confined by morally ambiguous circumstances. From this perspective, the humanism of the existential Marxists is at best naive, and possibly corrupt. Human beings are not "subjects" of history, they are history's objects. ${ }^{267}$ Individuality is associated not with the moral autonomy of conscience, but with the corruptibility of self-interest. Because this story portrays human beings as passive recipients of meaning, it supports the "anti-humanism" often attributed to structuralists and post-structuralists. ${ }^{268}$ Human values and choices are dictated by culture, rather than the other way around, say the structuralists. And for post-structuralists, culture is always hopelessly deceitful and contradictory. From these perspectives, the "authenticity" prized by existential Marxists is not possible.

This is the terrain in which Vergès wages his "judicial warfare." His arguments deliberately exploit this tension between idealism and cynicism that is the legacy of the Occupation to French popular culture. On the one hand, the French state, claiming descent from the Resistance, presents itself as the embodiment of humanity, courage and principle. On the other hand, the French people find it reassuring to discover that the world is a complicated place in which everyone is more or less corrupt and fraudulent. Vergès sets out to expose inauthenticity in a culture that simultaneously despises, expects, and enjoys it. While Vergès exploits this contradiction in French culture, he also exemplifies it. Moving from the humanist rhetoric of existential Marxism to the antihumanist rhetoric of structuralism and post-structuralism, Vergès' arguments reflect the French New Left's growing ambivalence concerning the concept of cultural authenticity.

The situation that gave birth to the French New Left in the late 1950's was the Algerian revolution. After a decade of political and moral confu-

265. Id. at 77-78.

266. Id. at 68, 105, 125-29, 243; K. SOPER, Humanism AND ANTI-Humanism 42-48, 54-74 (1986).

267. Solomon, supra note 12 (describing memoir of "nouveau roman" author Alain Robbe-Grillet, whose work is admired by structuralists for eschewing intention, motivation and emotion).

268. M. Poster supra note 263, at 324-26, 335-36, 340, 343, 354; K. SOPER, supra note 266, at 85-90, 96-115. See C. LEvi-STRAuss, The SAvage Mind 254 (1962) (critiquing French Left's belief that humans choose their history). 
sion prompted by the inconsistencies of Stalinism, ${ }^{268}$ progressive intellectuals coalesced in a protest against colonial repression that evoked the unity and moral certainty of the Resistance. ${ }^{270}$ For the French New Left, the French presence in Algeria was an Occupation, and the brutal French repression invited comparisons with the Holocaust. ${ }^{271}$

In this context, the French Communist Party was discredited by its Stalinism and lack of support for anticolonialist revolution. Vergès quit the party in 1957 "over the colonial question."272 With the party's decline, the central figure of the French New Left became Jean-Paul Sartre, whose stress on authenticity and commitment lent inspiration to Third World leftists. ${ }^{273}$ Most important among these was Frantz Fanon, a theorist of the Algerian revolution and admirer of the young Vergès. ${ }^{274}$ In The Wretched of the Earth, Fanon offered an existentialist psychology of authenticity and alienation to explain colonialism-particularly in Algeria-as the foreign occupation of the culture and psyche of the colonized. ${ }^{275}$ Fanon's thought influenced Che Guevara, who interpreted the improbable success of the Cuban revolution as a testament to humanity's freedom to interpret and change its conditions. Existential Marxism was appealing to those who, like Fanon and Guevara, saw national liberation as entailing the awakening of subjectivity, those who understood revolution as the heroic quest for identity rather than the rational pursuit of interest. ${ }^{278}$ To those who found their individual identities in a collective struggle, the potential tension between personal and culutural authenticity was not yet visible.

Representing Algerian revolutionaries in this intellectual milieu, Vergès saw the political lawyer as a mouthpiece for the authentic voice of the oppressed. Hence the political lawyer had to gain a hearing for the "human truth" of the political defendant. ${ }^{277}$ This involved revealing not only the social conditions that compelled the client's act of resistance, but

269. M. Poster, supra note 263, at 109-87; K. SoPER, supra note 266, at 79-85.

270. M. POSTER, supra note 263 , at 186.

271. Alain Resnais' much admired 1950's film on the deathcamps, NiGHT AND Fog, keeps the national identities of perpetrators and victims in soft focus. "The whole point," Resnais has explained, "was Algeria." Krantz, Alain Resnais" Nuit et Brouillard, in 3 Holocaust Studies ANnUal 107, 116 (S. Pinsker \& J. Fischel eds. 1985).

272. Hotel Terminus, supra note 32 (interview with Vergès).

273. M. POSTER, supra note 263 , at $186-87$.

274. F. Fanon, Toward The African Revolution 75 (H. Chevalier, trans. 1967) (on Vergès). Fanon anticipated some of Vergès' later arguments by criticizing the French Left for attempting to portray colonialism as contrary to traditionally French values. Id. at 83.

275. F. Fanon, The WRetched of THE EARTH (1961). This book contains an enthusiastic preface by Sartre.

276. See Binder, On Critical Legal Studies as Guerilla Warfare, 76 Geo. L.J. 1, 2, 10-11 (1987) (discussing voluntarist and psychological themes in Guevara's theories). While Geuvara makes no explicit references to existentialism, his work reflects the influence of Fanon. See S. Liss, MARXIST Thought IN LATIN AMERICA 257. For a voluntarist interpretation of Guevara's thought, see R. Debray, Revolution in the Revolution (1967) and R. Debray, Che's Guerrilla War (1975).

277. Defense Politique, supra note 86 , at 15 . 
the client's subjective values as well. The political lawyer's "duty is to help preserve the honor and dignity of his client ... [T] he accused's conception of his honor may be in absolute contradiction with the morals of his judges. The defense must help the judges overcome this 'wall of incomprehensibility." "2278 The political lawyer's role, therefore, was to help clients justify their resistance by articulating a distinctive standard of justice. ${ }^{278}$

Vergès saw such a defense as a form of resistance because he saw the silencing of the voice of the oppressed as a significant part of their oppression. "Silence is the supreme form of psychological warfare . . [ [w]e must break the silence of the prisons and their dossiers." 280 The trial provided a rare opportunity to speak, which "the European resistance against Hitler" lacked: "In the void behind closed doors, the struggle against torture and death continued-but the forum was lacking and so that struggle could not find voice."281 But through the courtroom, "a few cries have pierced the night and fog of the camps that have consumed two million Algerians." ${ }^{\text {282 }}$ Hence it was part of the resister's duty to speak in her own defense. ${ }^{283}$

The attorney, by contrast, had to be self-effacing, supporting the client's views rather than speaking her own, or those that would win the court's favor. Vergès denied that such a defense increased the client's risks, arguing that sensational publicity protects a political defendant from arbitrary treatment. ${ }^{284}$ Regardless of the merits of this claim, it is significant that Vergès defended political advocacy as consistent with an ethic of treating the client as an end in herself. Up to this point, Vergès advocated the client's politics in order to represent the client authentically, rather than use the client as the means to represent a political cause. At the close of the Algerian revolution, Vergès' conception of the political lawyer's role was circumscribed by the humanism then prevalent in the French New Left.

\section{Culture as Occupation}

Paradoxically, the success of Marxist humanism was its own downfall. The disaffection with dialectical materialism that had created space for existential Marxism in Europe and the Third World forced the Soviet

278. Id. at 26, (quoting Pierre Stibbe).

279. Id. at 60 .

280. Id. at 59-60.

281. Id. at $35-36$.

282. Id.

283. Id. 35-41 (Obligation of those who appear in court is to give voice to those who suffer in obscurity and to make use of a forum made available by struggle and protest. Purpose of such testimony is not to elicit pity from enemies or third parties, but to inspire one's comrades with hope. Hence, political defendant emphasizes goals of struggle, not its cost.).

284. Id. at $67-75$. 
Union to unveil its own official version of Marxist humanism. The emerging Sino-Soviet split of the early 1960's, however, prompted the Chinese Communist Party to attack the new humanism as bourgeois revisionism. ${ }^{285}$ Suddenly, the ideology most associated with national liberation was being condemned by the original prototype for all national liberation movements.

While the official Chinese propaganda of the early 1960's was as vacuous as the Soviet slogans it attacked, Sartre's version of Marxist humanism was in fact poorly adapted to movements modeled on the Chinese revolution. Chinese revolutionaries had aimed to mobilize existing communities rather than to fuse atomized individuals into a movement. Because they sought to realize indigenous agrarian socialist traditions, they foreswore the cosmopolitan cities in favor of guerrilla warfare in the countryside. Hence, Mao's theoretical writings envisioned each nation pursuing an idiosyncratic pattern of development towards communism, in realization of its own distinctive culture. ${ }^{286}$ The authenticity Maoism pursued was cultural authenticity, not personal authenticity.

Because Maoists saw identity as culturally rather than individually determined, they could not accept the existential Marxist vision of individuals freely creating their own identities. Reflecting the individualism of Western culture, existential Marxism was easily seen as a form of cultural imperialism. In addition, Maoists were inclined to see the existential Marxist emphasis on unconstrained subjectivity as a bourgeois concern that obscured class conflict. Existential Marxism seemed excessively concerned with the oppression of the wealthy, trapped in alienating roles and burdened with material objects.

These two weaknesses were exposed in an attack on existential Marxism launched by structuralists Claude Lévi-Strauss and Louis Althusser that coincided with the official Chinese polemic generated by the SinoSoviet split. Lévi-Strauss argued that human consciousness was conditioned and structured by culture. ${ }^{287}$ This meant that human nature was neither universal nor individual and that the Western admiration for "subjectivity" was merely a cultural artifact of no universal normative significance. ${ }^{288}$

Althusser, by contrast, dismissed the concept of "subjectivity" as bour-

285. K. SOPER, supra note 266 , at $86-88$.

286. See G. Binder, Treaty Conflict and Political Contradiction 117, 201-02 (1988).

287. See generally C. LÉvi-STRAuss, The SAvage Mind, supra note 268, at 254-55 (meaning is received rather than chosen; all meaning is "internal" to culture); M. Poster, supra note 263, at 306-32.

288. The concluding chapter of Lévi-Strauss' The SAvage Mind, supra note 268, is an attack on Sartre's existential Marxism as imperialistic. See id. at 248-49, 257-58 (Sartre's associations of humanity with subjectivity and of subjectivity with historical consciousness slight and dehumanize nonwestern societies); id. at 254-56 ("history" and "subjectivity" are "myths," "internal" to western culture); id. at 247,262 ("humanism" wrongly views all human beings as fundamentally alike). 
geois ideology. ${ }^{289}$ Where Lévi-Strauss saw conscious experience as dictated by culture, Althusser saw conscious experience as dictated by a "structure" that functioned to maintain existing "relations of production."280 According to Althusser, all culture was ideological and all ideologies "subjected" people by imposing individual identities on them. ${ }^{291}$ Apparently rooting his conception of culture in Western society, Althusser saw all culturally-conferred identity as sustaining an illusion of individual autonomy.

While Lévi-Strauss valued the cultures that structured experience, Althusser presented the ideologies that structured experience as woven into the straitjacket of capitalism. Where the structuralism of Levi-Strauss was at least compatible with the ethic of cultural authenticity embraced by national liberation movements, Althusser's structural Marxism denied that culture could be a liberating force. Althusser cited Mao's essay On Contradiction in support of a pessimistic view of capitalism as stable because "overdetermined."292 Yet Mao's essay expressed the optimism of a successful Marxist revolutionary in a country where capitalism never took root. Unlike Althusser, Mao saw history as indeterminate, pregnant with opportunity. ${ }^{293}$

Althusser's thought was incompatible with the faith in culture needed to sustain national liberation movements. But because he cited Mao, and because his antihumanist rhetoric resonated with the antihumanist propaganda emanating from Peking in the early 1960's, French Maoists like Vergès embraced Althusser. ${ }^{284}$ As a result, these supporters of national liberation found themselves increasingly confused, celebrating Third World cultures as inherently liberatory, while deploying a eurocentric Marxist analysis that dismissed all culture as oppressive.

To make matters worse, structuralism soon evolved into the still more

289. M. Poster, supra note 263, at 343-46; K. SOPER, supra note 266, at 104-05. L. ALThusser, For MARX 10-12 (B. Brewster trans. 1970) [hereinafter For MarX] (all humanism, including Soviet version, is ideological); id. at 25 (humanism is bourgeois); id. at 221-22 (Soviet humanist slogans attacked); id. at 230-31 (humanism is ideology which was opposed by mature Marx); L. Althusser, Lenin and Philosophy and Other Essays 170-71 (B. Brewster trans. 1971) [hereinafter LENIN AND PHILOSOPHY] (concept of subject is part of bourgeois ideology).

290. See generally Lenin AND PHILOsophy, supra note 289 (ideology helps "reproduce" labor, one of factors of production, by fitting individuals into existing "relations of production").

291. According to Althusser, ideology is false and should be distinguished from science. For MARX, supra note 289, at 166-73, 183-93. All societies are reducible to economy, politics, and ideology. Id. at 231-32. Ideologies are "perceived-accepted-suffered cultural objects." Id. at 233. "The category of the subject is constitutive of all ideology." LENIN AND PHILOsOPHY, supra note 289. "Subjects" are people "subjected" by the belief that they are "author of and responsible for their actions." Id. at 182.

292. See 1 Selected Works of Mao TSe Tung 311-37 (1967); For MarX, supra note 289, at 94, 182-83, 193-94, 201, 211 (discussion of Mao's essay); id. at 99, 104-06 (revolutionary change must be "overdetermined" because stability of capitalism is "over-determined").

293. 1 SELECTED WORKS OF MAO TSE TUNG 337 (1967) (indeterminacy and dynamism of identity); id. at 341-42 (stability is ephemeral, change is constant); id. at 344 (expressing optimism about socialist revolution everywhere); id. at 341 (capitalist stage can be skipped in Asia).

294. K. SOPER, supra note 266 , at 88 ; M. Poster, supra note 263 , at $359,375$. 
fashionable post-structuralism of Althusser's "student" Michel Foucault ${ }^{298}$ and Foucault's "disciple" Jacques Derrida. ${ }^{296}$ For Foucault, culture was the violent and exclusive product of power; it invaded and inhabited whatever it purported to represent. ${ }^{297}$ For Derrida, culture was not only violent, but incomplete, deceitful, contradictory. ${ }^{298}$ From this perspective, Third World revolutionaries were precluded from resisting foreign occupation on behalf of indigenous culture, because culture was itself a form of occupation. Revolutionaries could no longer hope to discover their authentic identities in the experience of struggle or the traditions of their people. The French left continued to support national liberation movements, but it began to abandon the ethic of authenticity that had originally identified such movements with its own Resistance. After squandering a chance for power in 1968, the New Left seemed incapable of sustaining its own identity. ${ }^{299}$

It was in this context, shortly before his disappearance, that Vergès developed a new conception of political advocacy, which he called defense by "rupture." ${ }^{300}$ No longer attempting to gain recognition for the political defendant's humanity, Vergès now advocated using the trial to illustrate a breach of communications with the judicial system. Rather than being broken down, the "wall of incomprehensibility" the defense attorney's refusal to collaborate with the judicial proceedings. Now Vergès completely subordinated the client's individual interests to the expression of the client's political ideas. ${ }^{302}$ Nor were these ideas any longer viewed as integral to the client's subjectivity: "[T]he personality of the man in the dock is left to one side: the debate is purely political." The client had become dispensable.

\section{Occupying the Occupier}

Vergès' decision to represent a committed Nazi reflected a further evolution in the ethics of his advocacy, beyond the impersonal detachment of the structuralist, to the paralyzing cynicism of the post-structuralist.

295. FOR MARX, supra note 289 , at 257 (identifying Foucault as his student).

296. J. DerRida, Writing AND Difference 31 (A. Bass, trans. 1978) (acknowledging "studying under" Foucault and describing self as Foucault's "admiring and grateful disciple"). Foucault's actual instruction of Derrida consisted only of preparing Derrida for university entrance exams.

297. See generally M. Foucault, Two Lectures, in PowER/KNOwLEdge 78-108 (1980).

298. See infra Section IV.

299. K. SOPER, supra note 266 , at $88-90$.

300. J. Vergès, De la STRategie Judiciaire (1968). The term "rupture" (spelled the same way in French and English), apparently fashionable among French intellectuals in the late 1960's, is used frequently in J. DERRIDA, supra note 296. See, e.g., id. at 71 ("language is the rupture with totality itself'). It is also used by Althusser in For Marx to describe contradictions that precipitate revolution and to describe the mature Marx's break with humanism. FoR MARX, supra note 289, at $99,227$.

301. See supra note 278 and accompanying text.

302. J. VERGÈs, supra note 300 , at 104.

303. Id. at 103 (quoted and translated in A. CASSESE, supra note 28, at 114). 
Vergès could represent Barbie because he no longer felt ethically constrained to identify with the personality or even the politics of his client. Like Barbie, he likened the SS to the French and Israeli armies, but hardly for the purpose of valorizing the SS.

Vergès no longer feels obligated to identify with his clients' politics because he no longer feels capable of identifying with any politics. Rather than displaying a rupture between the normative worlds of the state and of his client, Vergès deployed his client to display a rupture within French society. "The offense, the crime, is the revelation of a fracture in the social order," he said in an interview. ${ }^{304}$ "There is no social order without fractures." "305 Vergès argued that Barbie's trial "is a kind of ritual ceremony. They want, by spilling his blood, to do like they do when killing a goat, exorcise some evil." ${ }^{308} \mathrm{He}$ claimed no interest in Barbie, ${ }^{307}$ but "given the person not real, but mythological, manufactured for political reasons . . . I think it is the duty of a lawyer to defend him." scapegoat is to unify society by expelling a symbol of violence, ${ }^{309}$ Vergès sought to rupture French society by forcing it to accept Barbie as a fellow imperialist. Vergès sought to disrupt the sacrifice by holding the scapegoat hostage, by occupying him. "I am the scapegoat of this trial!" Vergès announced, in apparent satisfaction. ${ }^{310}$

Thus if Vergès no longer feels bound by fidelity to his client, neither does he seem bound by fidelity to himself. Vergès dons the mantle of legal authority, claiming that "I am alone in saving France's judicial honor," while admitting that "my law is to be against all law. My morality is to

304. Ulbrich, Barbie's Lawyer, AP, Oct. 13, 1985 (NEXIS).

305. Id.

306. Ulbrich, supra note 227. "By killing an old man, some French are trying to think that they are heroes." Ulbrich, Barbie Says Trial Feels Like Nuremberg, AP, May 12, 1987 (NEXIS). In the title of the book in which he "exposed" the betrayal of Moulin, Vergès referred to Barbie's judges as "Pontius Pilate," implicitly likening Barbie to Christ. See Pilate, supra note 205.

307. After hearing Vergès' elaborate rationale for defending Barbie, one observer asked him, "You felt the need to say many times, 'I am not defending Barbie.' Then who is?" J. Vergès, supra note 213 , at 28.

308. Ulbrich, supra note 304.

309. For the post-structuralist literary theorist Rene Girard, all cultural expression is ritualistic, involving the perpetual reaffirmation or group identity. Group identity is reaffirmed by symbolically purging the violent conflict that always threatens society. This involves identifying conflict with a symbol-a scapegoat-that can be cast out of society, implying that conflict is external to the group. See supra notes 143, 144. From this perspective, all symbolism or representation is a form of scapegoating, involving violence and deceit; and all identity rests, in turn, on representation. Thus all identity is rooted in deceit and violence.

Girard's view that culture is entirely devoted to purging irrepressible violence and irredeemable guilt seems appropriate in the wake of the Holocaust, but its depressing implication is that the cultures with which we identify, far from preventing carnage, rationalize it. Certainly the German identity promoted by the Nazis was rooted in the sacrifice of the Jews; and Vergès may be right that postwar French identity substitutes the condemnation of Nazism for the pursuit of liberty, equality, and fraternity. In a slightly different vein, Holocaust Judaism rests on exclusion by the other instead of exclusion of the other, but it also despairs of building community on the basis of shared ideals. Girard's view that group identity is necessarily built on sacrificial symbolism makes sense of these responses to the Holocaust-but at the cost of making the Holocaust itself appear sensible.

310. Rosemberg, supra note 259. 
be against all morality." ${ }^{311}$ Having deconstructed the ethic of authenticity, the French New Left now resists not Occupation, but identification. Receiving film interviewer Marcel Ophuls in his office, Vergès' demeanor is unabashedly artificial, flamboyantly studied, revealing nothing but a frank contempt: "You know I deceive you," his bland smile seems to say, "and yet I deceive you still." 312

Like many on the French left, Vergès reacted to the Occupation by associating collaboration with inauthenticity. Identifying with anticolonial resistance, Vergès aspired to represent the authentic voice of the occupied. Like many on the French left, however, Vergès has lost faith in the possibility of authenticity. The "wretched of the earth" still cry out for selfdetermination, but Vergès can no longer believe that anyone has a true self. Seeing collaboration everywhere, he has deconstructed the resistance he once aspired to represent.

\section{The Deconstruction of Identity as a Representation of NAZISM}

Both sides in the Barbie trial represented their causes by contrast to Nazism. This Commentary's analysis of the rhetoric of each side has revealed that both identified themselves as opponents of Nazism because of doubts about the credibility of their own beliefs.

Barbie's prosecutors participated in a tradition of Holocaust response that canonizes victims of Nazism as sacrificial martyrs. This Commentary has argued that Jewish participation in this sacrificial tradition is ill-advised because it rationalizes Jewish suffering as the price for gentile recognition of Jewish identity; because it compromises Jewish identity by representing it within a Christian symbolic framework; and because it questions the authenticity of Jewish identity by representing it as the product of persecution rather than self-determination.

Barbie's attorney participated in a leftist tradition of response to the Occupation that associates inauthenticity with Nazism. When postwar existentialists saw conformity as inauthentic, Vergès came to see law as repressive and deceitful. When 1960's structuralists saw individuality as illusory, Vergès concluded that the individual client was of no consequence. After post-structuralists announced that culture was inherently alien and deceptive, Vergès came to treat even his own anti-colonialism as a mask. Hence, this Commentary has argued that national liberation movements and leftist lawyers are both ill-advised to embrace post-structuralism: if there can be no authentic identity then there can be neither a foreign occupation to resist, nor a client to represent.

This Commentary's concluding Section explores the connection between

311. Rosemberg, supra note 4.

312. See Hotel Terminus, supra note 32. 
the postwar identity crises of Judaism and French leftism. Although antagonistic at the Barbie trial, post-structuralism and Holocaust Judaism are both symptoms of a common culture of despair that paralyzes moral choice in the wake of Nazi atrocities. Because those atrocities were perpetrated by large numbers of ordinary people, postwar society is permeated by anxiety that any of its members might have participated, collaborated or acquiesced under similar circumstances. Believing that, like Nazism, all creeds define themslves by their antipathies, members of postwar society eschew commitment to any cause for fear of becoming complicit in future atrocity. The only relief from such moral paralysis rests in the recollection of Nazi crimes, because they constitute the only evil one can despise without fear of becoming a Nazi oneself.

The despair common to post-structuralism and Holocaust Judaism is illustrated by Jacques Derrida's "deconstruction" of identity. Probably no one has contributed more to the French left's disenchantment with cultural authenticity than this Algerian born post-structuralist. Yet this Section will argue that Derrida, a Sephardic Jew, developed his critique of cultural authenticity as a form of Holocaust Judaism. ${ }^{\mathbf{3 1 3}}$ Seeing all identity as defined by exclusion, he views even his own Jewish identity as tainted by the "logic" of Nazism. Yet in defining deconstruction as opposition to Nazism, he employs the very logic he condemns. In so doing, he unacceptably implicates those who identify with Judaism in their own persecution.

I would characterize Derrida's deconstruction as a form of Holocaust Judaism because it expresses the alienation from Judaism of a writer deeply engaged with the Jewish tradition, because that alienation is a response to Nazi atrocities, and because the condemnation of those atrocities provides him with a way of being Jewish that does not require faith in any creed. The discovery that Derrida's deconstruction of identity can be seen as a Holocaust response does not mean that the identity crisis of the French left is caused by the crisis of Jewish identity. One could just as easily reverse the causation since Wiesel, the foremost exponent of Holocaust Judaism, first formulated his response to the Holocaust under the influence of French existentialism. ${ }^{314}$ Nevertheless, the Jewish context of Derrida's critique of identity reveals that post-structuralism and Holocaust Judaism share a common cultural milieu: both emerged as part of a postwar world determined to define itself in terms of its antipathies rather than its convictions. This is the world of the Barbie trial, a world in which Nazi atrocities, though universally regretted, are represented as a valuable learning experience.

313. See Spivak, Translator's Preface to J. Derrida, Of Grammatology ix (1976).

314. Wiesel writes in the adopted language of French and apparently modeled his style on that of Camus. See generally Lamont, supra note 184 . It takes little imagination to see his despairing theology of the absurd as reflecting the influence of existentialism as well. 


\section{A. Deconstructing Identity}

A reading of two essays in Writing and Difference ${ }^{315}$ will reveal Derrida's deconstruction as a post war comment on the problem of Jewish identity. In Edmond Jabès and the Question of the Book, ${ }^{316}$ Derrida rejects the idea that Jewishness makes Jews identical to one another or identifies them all with any one thing. In Violence and Metaphysics: An Essay on the Thought of Emmanuel Levinas, ${ }^{317}$ Derrida attacks the very concept of identity as intolerant and "violent."

In The Question of the Book, Derrida explicitly questions whether one can speak of "the Jewish community." "318 Like much of Derrida's work, this essay attacks the idea that a group or culture can be identified-unified, made the same-by adherence to scripture, because scripture is always contradictory, disjointed. For Derrida, as for Wiesel, God has nothing meaningful to say to humanity. "God," writes Derrida, "separated himself from himself in order to let us speak. . . . He did so not by speaking but by keeping still, by letting silence interrupt his voice, . . . by letting the tables be broken." ${ }^{1819}$ God's silence, His mystery, makes possible "our writing, certainly, but already his, which starts with the stifling of his voice and the dissimulation of his face. This difference, this negativity in God is our freedom." ${ }^{\text {320 }}$ God dissembles and His scripture hides His face which "no man may look upon." 321 God, concludes Derrida, "is not truthful, he is not sincere." 322 For Derrida, scripture cannot unify, it cannot be a source of identity because its author, God, is not one.

This position is so contrary to Jewish belief that it calls into question its author's Jewish identity. Derrida attributes this apostasy to the poet Edmond Jabès, but with obvious sympathy. Jabès, he insists, is Jewish in the sense that he is following the footsteps of other Jews into exile from Jewishness, from the law: "Negativity in God, exile as writing, the life of the letter are all already in Cabala. Which means 'Tradition' itself. . . . But traditionality is not orthodoxy."323 Jabès, and by extension Derrida, can be Jewish by virtue of their contribution to a tradition of speculation and commentary, even though they are unorthodox, that is, they do not accept the authority of Jewish law. ${ }^{\mathbf{3 2 4}}$

315. J. DERRIDA, supra note 296.

316. Id. at $64-78$.

317. Id. at 79-153.

318. Id. at 74 .

319. Id. at 67 .

320. Id. These passages are strikingly reminiscent of Wiesel's statement that "Within our tradition we know what God said at Sinai. But there are certain silences between word and word. . . . This is the silence I have tried to put into my writing." 1 E. WIEsel, supra note 1, at 273.

321. Exodus 33:20-23.

322. J. DERRIDA, supra note 296 , at 68 .

323. Id. at 74.

324. Derrida further complicates the question of his own identity and that of his "subject" Jabès, by ending the essay with a "signed" quotation from Jabès' fictional character "Reb Rida." In so 
Derrida seems especially concerned that Jabès will not be accepted by other Jews because of his treatment of Jewish suffering, of the Holocaust, in universalist terms. "You are all Jews," " he quotes Jabès, " "even the antisemites, for you have all been designated for martyrdom." "325 Jews, however, "will all reproach him for this universalism."326 Yet for Derrida, ambivalence about Jewish identity makes Jabès "more Jewish." Derrida concludes that " $[\mathrm{t}] \mathrm{he}$ Jew's identification with himself does not exist," because ambivalence between particular identity and universal significance is essential to Judaism..$^{328}$ Derrida critiques Jewish identity as divided between insularity and universality; yet his own critique proves to be divided as well. Because Judaism is contradictory, he argues, it cannot identify Jews with one another, or even with themselves. This is a critique of Judaism as inadequate to the full particularity of Jews. Yet he also expresses anxiety that this internal critique of Judaism will be interpreted as "too universalistic"-in other words, as reflecting a desire to identify with gentiles, to betray one's own particularity in the face of antisemitic persecution.

In Violence and Metaphysics, Derrida defends himself against this potential accusation of betrayal by arguing that Jewish identity is not only contradictory, but also immoral. Violence and Metaphysics is a critique of the existentialist philosopher Emmanuel Levinas' effort to reconcile Jewish identity with openness and tolerance toward strangers. In Totality and Infinity, ${ }^{329}$ Levinas asks his readers to identify themselves without relying on a biblical scripture that purports to account for all creation and to legislate all human behavior. Levinas rejects the image of God as totally omniscient and omnipotent because it eliminates the human freedom prized by the existentialist. ${ }^{330}$ Rather than abandoning religion, however, he invites his readers to worship a God that is infinitely mysterious rather than infinitely knowledgeable and powerful. Thus, he redefines the wonder of God's creation as its infinite indeterminacy rather than its total determinacy and transforms the creator from exacting lawgiver to fecund artist. By worshipping a God that is infinitely remote, infinitely other, people can be drawn together, but they will also be encouraged to respect

\footnotetext{
doing, Derrida claims a place in the rabbinic tradition, and questions whether the "Jabès" Derrida interprets is his own invention, or whether Jabès creates Reb (der) Rida in the act of being read by him. Id. at 78; see also id. at 300 (additional essay on Jabès signed "Reb Derissa," another of Jabès' characters).

325. Id. at 74-75.

326. Id.

327. "In this noncoincidence of the self and the self, he is more and less Jewish than the Jew." Id.

328. Id. ("The Jew is split. . . . His history would be but one empirical history among others if he . . nationalized himself within difference. . . . He would have no history at all if he let himself be attenuated within . . . an abstract universalism.").

329. E. Levinas, Totaliry AND Infinity (A. Lingis trans. 1969).

330. Id. at 292-94 (totality opposed to infinity, which Levinas equates with freedom).
} 
the otherness of their fellow humans. ${ }^{331}$ Accordingly, by imagining God as infinitely other, Jews can affirm their own particularity, their own distinctness, while accepting gentiles as divine creations, reflecting the mystery of God. ${ }^{332}$

While Derrida shares Levinas' hostility to the harsh determinacy of scripture, he rejects Levinas' effort to ground a specifically Jewish identity in infinite distance from an admired other. Although Derrida lobbies for the recognition of difference in every context, he argues that recognition of difference requires some similarity, some basis for communication. Thus to identify oneself as radically different from others, to learn to be tolerant of the "infinite otherness" of strangers, is to isolate oneself behind a wall of silence. And this, argues Derrida, is the ultimate "violence." 333

For Derrida, such silence is violent because tolerance without communication is nothing more than the cruel indifference of a self-sufficient God. ${ }^{334}$ Perhaps too, an abstract commitment to tolerate an infinitely distant other is compatible with violent efforts to expel or suppress the stranger in one's midst. But there is another, more frightening sense in which isolating oneself behind a facade of tolerance can lead to violence. Quite simply, isolation leaves a community conspicuous and vulnerable to sacrificial violence, as the Jews of Europe discovered. In equating noncommunication with violence, Derrida seems to admonish Jews that collective isolation is not only unethical but also imprudent. Recognizing another's difference is a fine thing, he seems to say, but insisting on your own difference can get you killed. Behind Derrida's moral argument for assimilation lurks fear.

Derrida has learned his assimilationism from the Holocaust. In its

331. "Infinity . . cannot be as violent as is totality." J. DerridA, supra note 296, at 107; see also E. Levinas, supra note 329, at 292 (infinity contrasted to totality). According to Derrida, Levinas sees God as infinitely other, and because Levinas sees all otherness as resembling God, he believes all relations with others are made possible by religious faith. J. DiRrIDA, supra note 296, at 95-96, 104, 107, 108; see E. Levinas, supra note 329, at 292-93 (otherness a miracle, facilitating divine creation); see also id. at 291, 305 (pluralism is the good).

332. Levinas never makes the Jewish focus of Toral.I'Y AND INFINIrY explicit, but as Derrida remarks, at its "heart" is "the face of Yahweh, who of course is never named." J. DeRRIDA, supra note 296, at 108. Levinas does, however, admit the thorough influence of Jewish theologian Franz Rosenzweig's "opposition to the idea of totality," on Totality and Infinity. E. Levinas, supra note 329 , at 28. Rosenzweig devalued the modern state in favor of family and and descent, which he saw as the source of Jewish identity and eternity. E. Berkovits, Major Thrmes in Monkrn PhIlosophiss of JuDAISM 40-41 (1974). Rosenzweig identified Jews as strangers everywhere, even from God, whom they must address in foreign language, as opposed to Christians, who humanize God in order to reduce His otherness. Id. at 41-43. Because of this fear of the other, Christianity is expansionist. It is historical, whereas Jewish acceptance of otherness makes it ahistorical. Id. at 43-46. Without naming it as Jewish, Levinas advocates this conception of identity. See E. Lkvinas, supra note 329, at 268-69, 282-85 ("fecundity" (family life) relates individual to eternity). J. Dr.RRIDA, supra note 296, at 94, 97 (Levinas sees acceptance of otherness as ahistorical, while seeing historicism as totalitarian); E. Levinas, supra note 329 , at 252 (antistatism).

333. J. DrRrida, supra note 296 , at $117,130$.

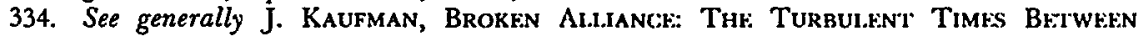
Bl.ACKs AND Jkws IN AMERICA (1988) (example of limitations of abstract tolerance of stranger in modern Jewish life). 
wake, he fears that to define himself at all is to incorporate what he considers the Nazi logic of defining the other outside of oneself. Yet in defining his own deconstruction by contrast to this logic, he does incorporate it. Deconstruction is not Nazism, but its influential critique of identity depends upon an identification of Judaism with Nazism that misrepresents both.

\section{B. Deconstruction as a Representation of Nazism}

Derrida presents deconstruction as a response to Nazism in a reading of arguably pro-Nazi writings by the late Paul de Man, an important deconstructive theorist. An originator with Derrida of deconstructive criticism, de Man was recently discovered to have authored a number of essays for a collaborationist newspaper in occupied Belgium during World War II. One of these articles, The Jews in Present Day Literature, ${ }^{335}$ concludes that European culture would suffer no loss if Jews were eliminated from Europe. The discovery of this essay prompted accusations that deconstruction is tainted with Nazism.

The bases for this suspicion of deconstruction are threefold. First, because deconstruction shows every argument to contain its own opposite, it seems nihilistic. Second, because deconstruction is said to "annihilate the subject"- to deny the individual identities of authors and of characters-it seems to deny individual responsibility for evil. Third, because it exposes the futility of efforts to deny loss, contradiction and violence, deconstruction seems to urge acceptance of their necessity. ${ }^{336}$ Perhaps an "antihumanist" philosophy that attempts to annihilate the subject sees no great loss in the annihilation of subjects. ${ }^{337}$ In an anguished essay entitled Like the Sound of the Sea Deep Within a Shell: Paul de Man's War, ${ }^{\mathbf{3 3 8}}$ Derrida undertakes a difficult task: to justify deconstruction and to excuse de Man, without justifying the charge that deconstruction excuses antisemitism.

Derrida meets this challenge with his deconstructive critique of identity. He attempts to detach de Man's deconstruction from de Man's earlier antisemitism by denying that de Man can be identified with himself..$^{339}$ The problem with Derrida's effort to detach the deconstruction of identity

335. See Derrida, Like The Sound of The Sea Deep Within a Shell: Paul de Man's War, 14 GRTII:AI. InQUIRY 590 (1988).

336. See J. Cul.t.kR, supra note 143, at 93 (deconstruction critiques rhetoric of recuperation); K. Sortik, supra note 266, at 122 (pessimistic implications or deconstruction).

337. See K. Sopkr, supra note 266, at 10-12; M. Postke, supra note 263, at 319, 336-37 (antihumanist slogans of various structuralist and post-structuralist thinkers); see also Bernstein, Critics Attempt to Reinterpret a Colleague's Disturbing Past: The de Man Affair, New York Times, July 17,1988 , § IV at 6, col. 1 (late city final ed.) (deconstruction accused of nihilism); Solomon, supra note 12 (antihumanist New Novel associated with collaboration or political indifference).

338. Derrida, supra note 335.

339. See infra notes $343,356-358$ and accompanying text. 
from de Man's antisemitism is that Derrida's deconstructive arguments are anticipated by the antisemitic text he deconstructs. The Jews in Present Day Literature heaps contempt on Jews for having no distinctive identity, and expresses annoyance that their claims to distinction force de Man to express antisemitic opinions that are foreign to him. ${ }^{340}$ Because the young de Man's antisemitic text deconstructs itself in this precocious way, it is hard to credit Derrida's later claim that deconstruction is the opposite of antisemitism. . $^{\mathbf{4 1}}$

To make this claim plausible, Derrida is forced to redefine antisemitism in universalist terms, as "totalitarianism." tion responds to antisemitic persecution by denying that there is any such thing as a Jew. The following reading of Paul de Man's War reveals that deconstruction can excuse antisemites by refusing to identify them with their antisemitism; at the same time it can implicate Jews in their own persecution by claiming that it is "totalitarian" to identify as a Jew.

Derrida argues that the young de Man lacked commitment to the collaborationist and the antisemitic sentiments in his own essays, that he did not identify with them. Derrida points out ways in which the young critic's complex prose seemed to undermine the authority of his conclusions. Thus, Derrida notes de Man's ironic failure to heed his own prescient warning that politics is " "totally alien to [men of letters], so that when they venture onto this terrain in that offhand way that only the ignorant are capable of, one may expect the worst." "343 Yet this may be read as the protest of a young aesthete at being forced by his editors to write about politics, one who perhaps is more upset at having to collaborate with politics than at the politics with which he is forced to collaborate.

Consider Derrida's argument that The Jews in Present Day Literature is really an attack on "vulgar antisemitism." For the young de Man, antisemitism was vulgar if it rejected literary modernism as a Jewish invention. ${ }^{344}$ According to de Man, to notice any Jewish influence on European literature was to insult it: "It would be a rather unflattering appreciation of Western writers to reduce them to being mere imitators of a Jewish culture that is foreign to them. The Jews themselves have contributed to spreading this myth. Often they have glorified themselves." ${ }^{\text {345 }}$ Derrida is quite right in saying that de Man condemned "antisemitism as regards literature." ${ }^{346}$ The young de Man wanted to save modern literature from

340. See infra notes $345-353$ and accompanying text.

341. See infra notes 356-368 and accompanying text.

342. See infra notes 361-67 and accompanying text.

343. Derrida, supra note 335 , at 612 (quoting de Man).

344. Id. at 624 .

345. Id.; see id. at 625 (Derrida's unconvincing argument that de Man's ascription of this "unflattering myth" to Jewish vanity undermines the statement's antisemitism).

346. Id. 
antisemitism by denying its Jewishness, just as he wanted to save it from political repression by denying its politics. ${ }^{347}$

In de Man's defense, Derrida argues that de Man was pleading for the autonomy of literature from politics at a time when authors were being judged and persecuted for resisting Nazism rather than serving it. ${ }^{348}$ Hence de Man's hollow boast that European literature was free of foreign influence revealed an anxiety that the occupier's politics might invade his own literature: "If our civilization had let itself be invaded by a foreign force, then we would have to give up much hope for its future." 349

But whom does de Man blame for this predicament? To whom does he attribute this invasion? What is the "foreign force" that threatens to corrupt the literary sensibility that Derrida calls de Man's "culture?"sso Not Germans, but Jews: "By keeping, in spite of semitic interference in all aspects of European life, an intact originality, that civilization has shown its basic nature is healthy." having been successfully resisted, no longer threatens European culture. ${ }^{352}$ But in offering this argument, de Man also congratulates himself that he has prevented "vulgar antisemitism"363 from invading his own personal "culture." And if de Man has failed to resist antisemitism, he blames not himself, but the invader, who is not even the real invader, but the invader's favorite scapegoat, the Jew.

Thus the young de Man denied that he had been occupied by antisemitism on the grounds that he was not preoccupied by Judaism. Insisting that Jews did not influence him, he hoped to imply that Jews could not perturb him. The complex excuse already embedded in this text may explain why de Man never felt called upon to apologize for it in his later life. ${ }^{364}$

As Derrida suggests, de Man's deconstructive theory, which insists that language is always alien to its speaker, implies repentance. ${ }^{385} \mathrm{We}$ can

347. The "History of Art and literature . . does not merge with sociopolitical history." Id. (Derrida summarizing de Man's text).

348. Id. at 615,628 .

349. Id. at 631 .

350. Id. at 636 .

351. Id. at 631 .

352. Id. at 630 .

353. Id. at 624 .

354. Id. at 638. Derrida here suggests that de Man's silence on this subject was explained, if not broken, by a later essay; see de Man, Excuses (Confessions), in P. DE MAN, Allegories of ReAding (1979) [hereinafter Excuses].

355. A reading of Rousseau's Confessions, Excuses, id., asserts the futility of all attempts to excuse what one has said: "the text can never stop apologising for the suppression of guilt that it performs." Id. at 300. For the failure of excuses to excuse, de Man blames "a foreign element, that disrupts the meaning, the readability of the apologetic discourse, and reopens what the excuse seems to have closed off." Id. at 289-90. De Man's example of such a disrupted excuse is Rousseau's excuse for falsely accusing a friend, that he did so in order to excuse himself of the same misdeed. Id. at 288. It is this scapegoat, this friend, that for de Man is the foreign element that makes the effort to excuse oneself inexcusable. Where the young de Man was inclined with Rousseau to see such foreign elements as contingent, as not really influencing his language, the mature de Man acknowledges the 
imagine de Man congratulating what he calls the "foreign element" in his own language: Thank God, my friend that I could not eradicate you! Thank God I could not mean what I said! But de Man's theory also implies an excuse, one he has made before: After all, I could not say what I meant. My language was invaded. My cruelty towards you, though unavoidable, was not my own.

And Derrida, de Man's embarassed friend accepts this excuse: ${ }^{358}$ The de Man that was his friend, is not the de Man that wrote an antisemitic essay. Like the Jew, de Man is not identical with himself but is divided from his past by a "rupture." 367 Yet de Man's innocence is over-determined: bearing no responsibility for his past de Man has nevertheless rectified it. Thus Derrida insists that de Man's mature deconstruction always deconstructs de Man's own youthful writing. Between de Man's deconstruction and de Man's antisemitism, Derrida demands a "war."

Derrida insists on this war because Paul de Man's War is not merely a defense of Paul de Man, but a defense of deconstruction against the charge of antisemitism. Derrida's defense is that deconstruction is essentially opposed to Nazism and that deconstruction is also essential to opposing Nazism. Thus Derrida refers to Nazism, without naming it, as "what has always been for me the worst." ${ }^{\text {"s58 }} \mathrm{He}$ later argues that interpreting de Man's antisemitic article carefully fulfills a responsibility to the "victims of discourses that at least resembled" it. ${ }^{360}$ Next he claims that attempts to identify this early antisemitic article with de Man's later work are "guided by [the] principle of the worst totalitarian police."361 To identify de Man with himself is to seek a "historical totalization," that subordinates "discontinuities" to a "totaliarian logic."362 "Since we are talking at this moment about discourse that is totalitarian, fascist, Nazi, racist, antisemitic and so forth . . . I would like to do . . . whatever possible to avoid the logic of the discourse thus incriminated."363

But is this resistance to "the logic of totalitarianism" appropriate only because at the moment "we are talking of discourse that is totalitarian?" No, it quickly becomes apparent that this "rule" of interpretation applies to all discourse, not just de Man's: "a formalizing, saturating totalization

necessity, the ineradicability of such foreign elements.

356. Derrida describes the nationalist and antisemitic rhetoric of de Man's collaborationist essays as already familiar to him as part of a preexisting "ideological configuration," appropriated by de Man. Derrida, supra note 335, at 600.

357. Id. at $635,641,646,648$.

358. Id. at 594. This argument that de Man's deconstruction developed in reaction to his youthful error suggests that Derrida is not only defending de Man as a man capable of learning from his mistake-he is defending de Man's antisemitic essay as a mistake capable of teaching de Man the value of deconstruction.

359. Id. at 600 .

360. Id. at 631 .

361. Id. at 641 .

362. Id. at 641 .

363. Id. at 645 (emphasis in original). 
seems to me to be precisely the essential character of this logic whose project, at least, and whose ethico-political consequence can be terrifying. One of my rules is never to accept this project and consequence." ${ }^{364}$ Apparently Derrida is always talking of a "discourse that is totalitarian"; in fact, rejecting the totalitarian is precisely the purpose of deconstruction: "One must analyze as far as possible this process of formalization and its program . . . It has occurred to me on occasion to call this deconstruction." ${ }^{365}$ Deconstruction, in short, is this critical analysis of totalitarian logic. "What I have practiced under that name has always seemed to me favorable, indeed destined (it is no doubt my principal motivation) to the analysis of the conditions of totalitarianism in all its forms."'368

But Derrida goes still farther. Not only is deconstruction a response to the Holocaust, it is a necessary response: "[D]econstructions have always represented, as I see it, the at least necessary condition for identifying and combatting the totalitarian risk in all [its] forms." ${ }^{\text {(367 }}$ We cannot combat totalitarianism without deconstructing.

Why? Derrida's reason is the contradiction he leads us to expect in every text. We must deconstruct in order to combat the totalitarian logic of identity, because only deconstruction enables us to identify instances of totalitarianism: "Do we have access to a complete formalization of this logic? . . . Is there a systematic set of themes . . . which, forming a closed and identifiable coherence of what we call totalitarianism, fascism, nazism, racism, antisemitism, never appear outside these formations and especially never on the opposite side? . . . Is there some property so closed and so pure that one may not find any element of these systems in discourses that are commonly opposed to them? . . . I do not believe that there is."

\section{Conclusion: Representing Nazism}

This Commentary's reading of the Barbie trial has confirmed that "totalitarianism, fascism, Nazism, racism [and] antisemitism," are not the same thing, and so cannot be identified with one another. Accordingly, Derrida is correct that the atrocity to which they all refer cannot be identified or represented. The effort to represent Nazism is motivated by the hope of defining oneself in opposition to that atrocity. For some Frenchmen, the appeal of such an identity is the hope of deflecting the

364. Id. at 645 (emphasis in original).

365. Id. at 646 .

366. Id. at 648 .

367. Id. at 647. Note that this sentence contains qualifications, most importantly the insistence that deconstructive acts not be reified as "deconstruction." While it is admirable to avoid reifying ideas one is critiquing, a refusal to be identified with one's own ideas, or even to identify them, is a flight from responsibility. Recall that Barbie refused to reduce Nazism to definition. See supra notes 199-203 and accompanying text.

368. Derrida, supra note 335 , at 645 . 
charge of collaboration. For some Israelis, its appeal is the moral license it seems to grant their country. For some Jews, its appeal is simply the hope of having some identity after the catastrophic discrediting of the covenant that the Holocaust involved for them. So people represent Nazism in order to identify and justify themselves.

While rejecting identity as a Nazi concept, Derrida identifies deconstruction by contrast to Nazism; while acknowledging that Nazism cannot be represented, Derrida represents Nazism as the antithesis of deconstruction. Derrida is driven to these contradictions by the need to escape the dangers of being seen as a traitor to the Jewish people. Representing Nazism as totalitarianism rather than as antisemitism enables Derrida to distinguish his own critique of Jewish culture from the similar critique offered by the young de Man. Thus the young de Man's antisemitic text is "totalitarian" because it dismisses Judaism as superfluous for an essentially gentile culture. Rejecting the "totalitarian" concept of cultural identity, however, Derrida dismisses Judaism as superfluous even for Jews. According to Derrida, the young de Man's antisemitism is wrong not because it is hostile to Judaism, but only because it identifies individual Jews with Judaism. Hence, to retain a sense of Jewish identity after the Holocaust is, for Derrida, to be a totalitarian, a Nazi. Jewishness, alas, turns out to be an invader that must be expelled into exile.

Derrida's viewpoint is that Judaism is not a unity that can offer Jews an identity. Instead it is a problem, a set of issues, conflicts, or ambivalences. Jews cannot determine who they are by reference to a contradictory Jewish law. While they can participate in a tradition of commentary, that tradition has expressed the self-alienation of the victim of persecution. Hence Jews must disperse themselves in an alien world beyond Jewish tradition even in order to locate themselves within it. For Derrida, there can be no Jewish community because there is no unique Jewish nomos. Judaism is incoherent and incomplete, not just as a legal code but as a culture. For Derrida, Jewishness is a condition of isolating alienation and political powerlessness, dependent upon persecution. Hence Derrida's defense of de Man ultimately emerges as the claim that without antisemitism no one could remain a Jew. Derrida's deconstruction shows the convergence of Holocaust Judaism with assimilationism.

Because Jewish identity can get one killed, Derrida deconstructs the scripture in which it is rooted. Hence, like the most unorthodox Jewish theologian of the Holocaust, Richard Rubenstein, Derrida seems eager to shed his Jewish identity, now that the Holocaust has revealed that identity as neither authorized nor protected by God.

Having abandoned Jewish identity, Derrida redefines himself as an opponent of Nazism. Hence, like the most popular theologians of the Holocaust, Elie Wiesel and Emil Fackenheim, Derrida seems overly optimistic 
that an identity rooted in the Holocaust can substitute for the loss of Jewish values.

By representing Judaism as the totalitarian interpretation of scripture, Derrida implicates Jews in their own persecution. Hence, like the most orthodox theologians, who see Jewish suffering as the price of transgression, Derrida seems ready to accept Jewish responsibility for the Holocaust. Treating the Holocaust as an argument for deconstruction, Derrida resembles those theologians who see suffering as God's way of teaching a more rigorous practice of interpreting scripture.

Derrida is wrong that deconstruction is an adequate substitute for Jewish identity because he is right that Nazism cannot be a source of identity for Jews. Deconstruction demonstrates the futility of representing Nazism, but it does not prove that we are all Nazis any more than it proves Jabès' claim that "you are all Jews." And if it suggests that Jews be wary of "learning" their Jewishness from the Holocaust, it cannot convince me that the Holocaust teaches them not to be Jews.

Leftists in France and in the Third World must learn that deconstruction proves inadequate as a source of utopian political theory for the same reason that it proves inadequate as a source of Jewish theology. Arguing that no creed can be coherent, deconstruction denies that any polity can realize a distinctive nomos. If no individual can identify herself by reference to a creed, then no individual can claim that the realization of her identity depends upon that creed's embodiment in a political community. There can be no right of self-determination if there is no self.

Barbie's judges, prosecutors, and defenders all reified the highly questionable assumption that German atrocities were caused by a coherent and identifiable ideology. This assumption reassured the trial's spectators that they had only to condemn Nazism in order to identify the values in which they believed. Deconstruction advises its readers that they do better to avoid identifying their values in a world where Nazism is the only identifiable and coherent ideology. Yet the nocturnal world in which Klaus Barbie met his victims was misted in anonymity. Accordingly, I remain unconvinced that unspeakable crimes can be ascribed to any identifiable set of values. To my mind, the representations of Nazism offered at the Barbie trial were the cries of those trapped in a culture devoid of values. To live in such a culture is to join an endless procession of the nameless, bound in the night for an unknown destination. 